\title{
Maritimes Basin evolution: key geologic and seismic evidence from the Moncton Subbasin of New Brunswick
}

\author{
C. St. Peter \\ New Brunswick Department of Natural Resources and Energy, \\ P. O. Box 6000, Fredericton, New Brunswick E3B 5HI, Canada
}

Date Received October 19, 1993
Date Accepted January 31, 1994

The Maritimes Basin is a composite large $\left(148,000 \mathrm{~km}^{2}\right)$, post-Acadian internal successor basin. It comprises several early northeast- to east-trending, relatively deep, isolated subbasins which are covered by mainly regionally derived and widely distributed fluviatile sequences. The early basin fill in the Moncton Subbasin of southeastern New Brunswick is seen from stratigraphic and seismic reflection evidence to comprise two depositional sequences (allocycles) which are separated by a basin-wide unconformity. The basal cycle, the Horton Group, is a 3 to $5 \mathrm{~km}$ thick coarse-fine-coarse (alluvial-lacustrinealluvial) cycle. The medial lacustrine interval implies a period of rapid subsidence. The unconformably overlying allocycle, recorded by the Windsor and Hopewell groups, is a coarse-fine-coarse (alluvial-marine-alluvial) cycle. The marine part of the Windsor Group indicates a medial period of tectonic subsidence or eustatic sea level rise.

The depositional history of the Moncton Subbasin sensu stricto ended following Hopewell time when the subbasin was inverted by late Namurian deformation. The Hopewell and older basin fill is unconformably overlain by quartzose fluviatile sandstones with associated inter-channel mudstones and paludal deposits of the regionally distributed late Namurian/ Westphalian Cumberland Group. Cumberland rocks are succeeded by meandering(?) fluviatile strata of the late Westphalian/ Permian Pictou Group. An angular discordance between Cumberland and Pictou strata implies a period of uplift or regional tilting.

The tectonism that initiated and terminated the early allocycles and which is recorded by unconformities following Horton and Hopewell deposition is seen from structural data and seismic reflection profiles to have resulted from dextral transpression. Evidence includes a network of basin-parallel northeast-trending anastomosing faults (many with shallowly pitching slickensides), associated en échelon folds, and geologically and seismically identified positive flower structures. An interpretation of early Maritimes Basin evolution in a wrench setting is consistent with the many northeast-trending steeply dipping terrane boundary faults in the underlying basement and with most recently published evidence of Variscan (Alleghenian) orogenesis as resulting from dextral oblique collision of Laurentia and Gondwana.

Le bassin des Maritimes est un bassin successeur interne d'âge post-acadien, composite et de grandes dimensions $\left(148000 \mathrm{~km}^{2}\right)$. Il comprend plusieurs sous-bassins primitifs isolés, de direction nord-est à est, et relativement profonds, qui sont recouverts par des séquences fluviatiles largement réparties et de sources généralement régionales. On peut considérer que le remplissage initial du sous-bassin de Moncton au sud-est du Nouveau-Brunswick, d'après les données statigraphique et de sismique réflexion, comprend deux séquences de déposition (allocycles) séparées par une discordance sur toute l'étendue du bassin. Le cycle de base, le Groupe d'Horton, est un cycle grossier-fin-grossier (alluvial-lacustre-alluvial) de 3 à $5 \mathrm{~km}$ d'épaisseur. L'intervalle lacustre intermédiaire implique une période de subsidence rapide. L'allocycle recouvrant le tout en discordance, représenté par les groupes de Windsor et d'Hopewell, est un cycle grossier-fin-grossier (alluvial-marin-alluvial). La partie marine du Groupe de Windsor indique une période intermédiaire de subsidence tectonique ou de remontée eustatique du niveau de la mer.

L'histoire de déposition du sous-bassin de Moncton sensu stricto a pris fin après la période Hopewell quand le sousbassin a été inversé par une déformation au Namurien tardif. Le remplissage de bassin Hopewell et plus tardif est recouvert en discordance par des grès fluviatiles quartzeux avec des mudstones inter-chenaux et des dépôts paludiques associés du Groupe de Cumberland du Namurien tardif/Westphalien, de répartition régionale. Aux roches du Cumberland ont succédé des strates fluviatiles méandriques (?) du Groupe de Pictou du Westphalien tardif-Permien. Une discordance angulaire entre les strates du Cumberland et du Pictou implique une période de soulèvement ou de basculement régional.

Les données structurales et les profils sismiques suggèrent que la tectonique qui a initié et terminé les premiers allocycles et qui est représentée par des discordances faisant suite au dépôt d'Horton et d'Hopewell résulte d'une transpression dextre. Cette hypothèse est notamment confortée par un réseau de failles anastomosantes de direction nord-est et parallèles au bassin (plusieurs présentent des slickensides faiblement inclinés), des plis en échelon associés et des "flower structures» positives identifiées par les données géologiques et sismiques. Une interprétation de l'évolution initiale du bassin des Maritimes dans un contexte de décrochement est en accord avec les nombreuses failles de bordure de terrain dans le socle sous-jacent, d'orientation nord-est et fortement inclinées, et avec les données les plus récemment publiées indiquant que l'orogénèse varisque (alleghanienne) résulte d'une collision oblique dextre entre Laurentia et Gondwana.

[Traduit par la rédaction] 


\section{INTRODUCTION AND PURPOSE}

The Maritimes Basin (Fig. 1) is the largest post-accretionary intermontane basin in the Appalachian Mountain system (Williams, 1974). It has an area of $148,000 \mathrm{~km}^{2}$ of which about $70 \%$ is offshore in the Gulf of St. Lawrence and beneath the continental shelf. The sediment fill of the Maritimes Basin unconformably overlies a basement of deformed tectonostratigraphic zones or terranes.

The Maritimes Basin was named by Roliff (1962); it consists of several Upper Devonian to Lower Carboniferous subbasins filled with predominantly continental deposits. The subbasins are separated by crystalline uplifts (sediment sources). Both the subbasins and uplifts are entirely or in part buried by regionally distributed Upper Carboniferous to Permian strata.

The purposes of this paper are: (1) to describe the essential characteristics and cyclicity of the sedimentary fill in one of the early subbasins, the Moncton Subbasin of southeastern New Brunswick, and (2) to suggest from the geometry and interpreted kinematics of structural features, that oblique tectonics was the significant mechanism controlling depositional cyclicity.

\section{BASEMENT TERRANES}

The Late Devonian to Permian rocks of the Maritimes Basin (Fig. 1) unconformably overlie a complex collage of basement terranes that compose the northeastern end of the Appalachian orogen (Williams, 1979; Williams and Hatcher, 1982; Bradley, 1982; Keppie, 1985, 1992; Rast, 1989). The basement rocks range in age from Proterozoic Grenville gneiss to Middle Devonian plutonics, volcanics, and sedimentary rocks.

In the past twenty-five years several summary accounts of the geology and plate tectonic evolution of the northeastern Appalachian chain have been published (Bird and Dewey, 1970; Williams, 1979; Williams and Hatcher, 1982; Williams et al., 1988; Barr and Raeside, 1989; Rast, 1989; Keppie, 1992). The descriptive account and model which has gained widest acceptance is that of Williams (1979), and the later revision of this by Williams and Hatcher (1982). They divided the Ordovician and older basement rocks of the northeastern Appalachians into five tectonostratigraphic zones (Fig. 2). From northwest to southeast the zones are: Humber, Dunnage, Gander, Avalon, and Meguma.

The Humber zone represents the Proterozoic to early Paleozoic continental margin of eastern North America. It comprises Grenville basement overlain by a miogeoclinal sequence of Cambro-Ordovician clastics, carbonates, and local volcanics that are believed to represent the passive northwestern margin of the Iapetus Ocean. The southeastern margin of the Iapetus Ocean in the northeastern Appalachians is defined by the Gander zone (Williams, 1979). The Gander rocks are mainly metamorphosed and polydeformed pre-Middle Ordovician arenaceous strata, such as the lower Tetagouche Group of New Brunswick (Williams, 1979; Barr and Raeside, 1989). Paleozoic megacrystic granites, leucogranites, and pegmatites are common in the Gander terrane.

The Dunnage zone lies between and allochthonously upon the Humber and the Gander in Newfoundland (Williams et al.,

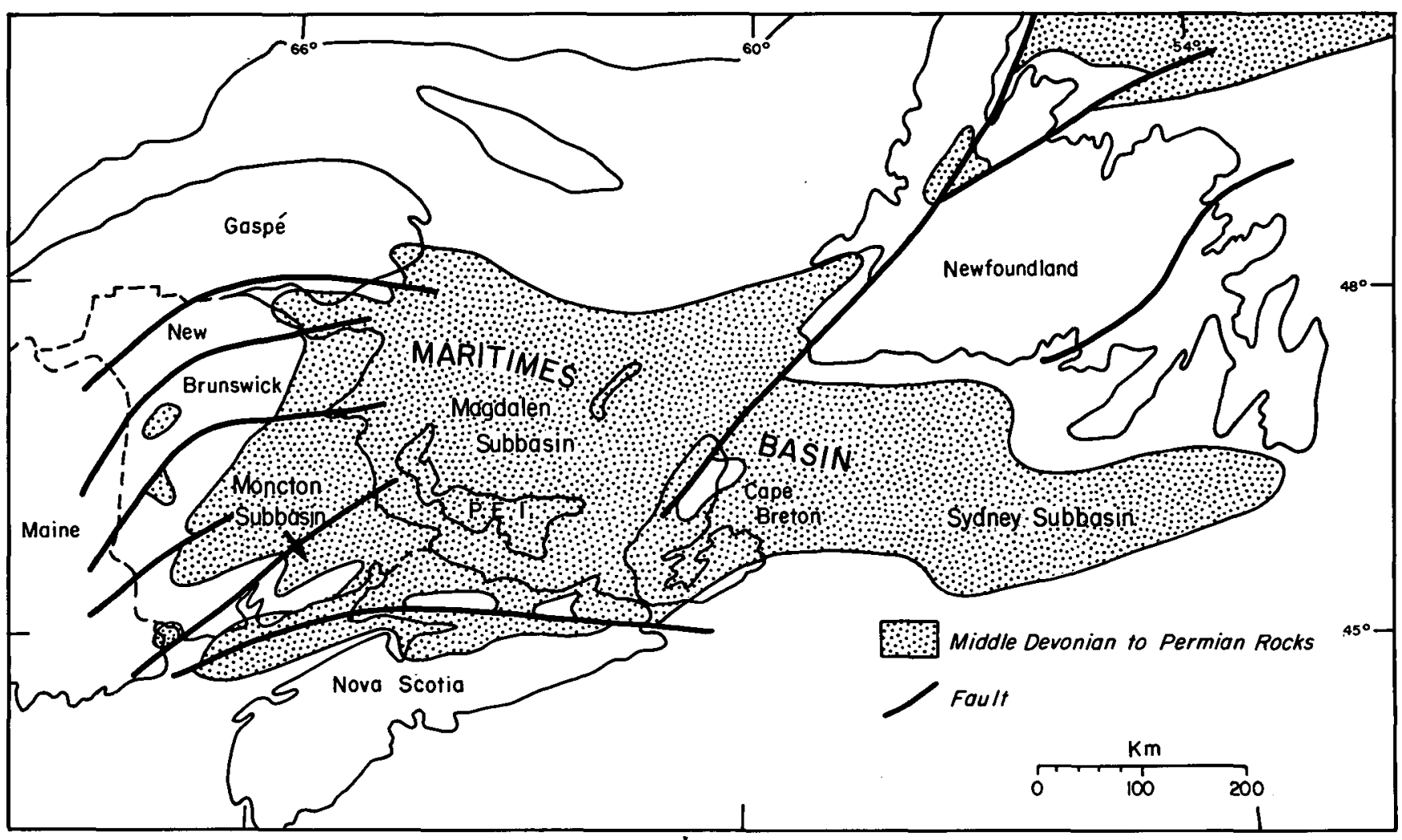

Fig. 1. Maritimes Basin showing the present erosional edge of mainly the Upper Carboniferous/Permian late sag phase of the basin (cf. Fig. 3). Taken from Roliff (1962), Williams (1974), Bradley (1982), and Fyffe and Barr (1986). 


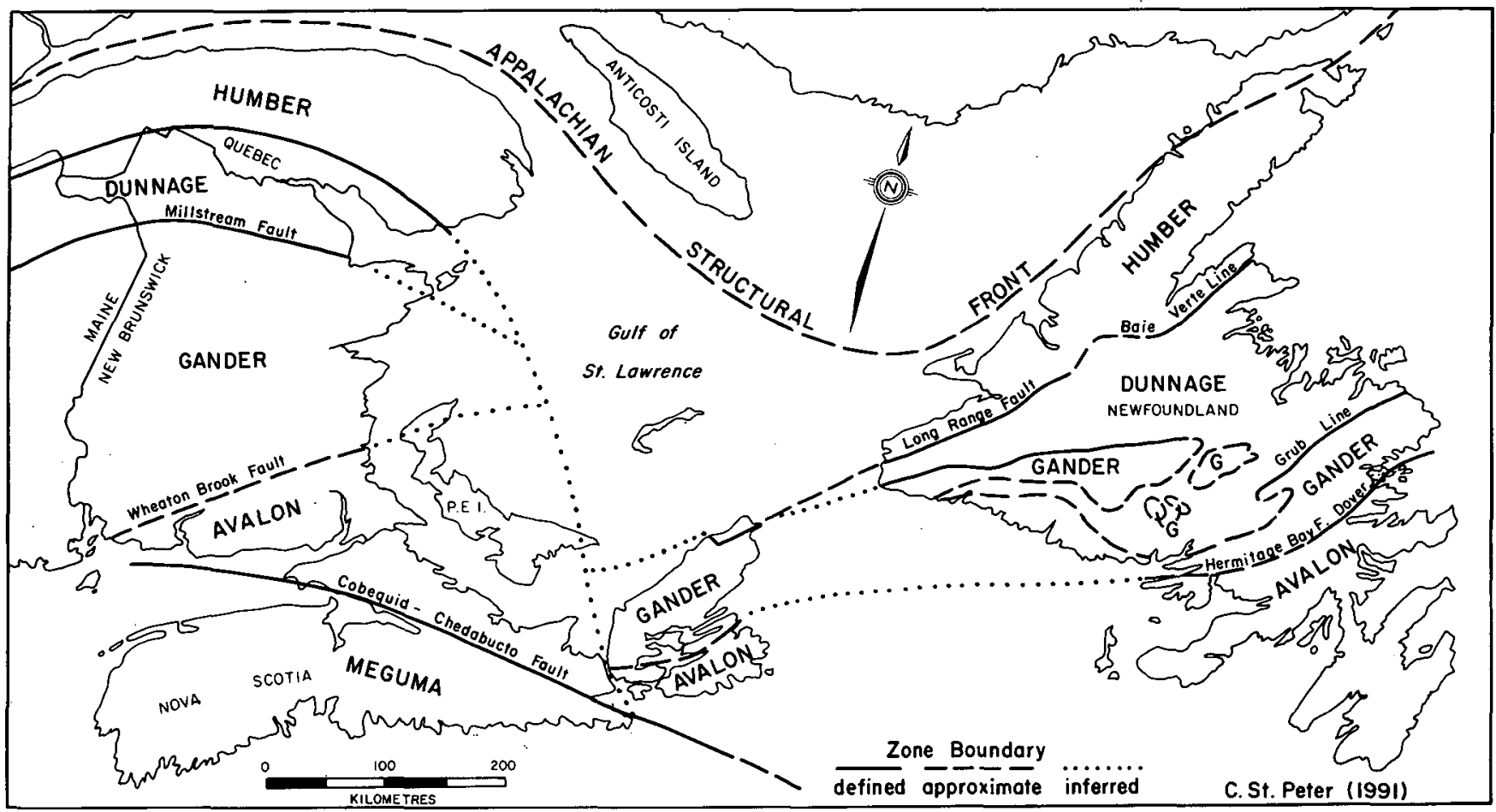

Fig. 2. Tectonostratigraphic zones of northeastern Appalachians; $G=$ Gander Zone "inliers" in Newfoundland. Compiled after Williams (1979), Williams and Hatcher (1982), McCutcheon (1981b), McCutcheon and Robinson (1987), Williams et al. (1988), Barr and Raeside (1989), Marillier et al. (1989), Durling and Marillier (1990), and St. Peter and Fyffe (1990).

1988). The Humber and Dunnage are in tectonic contact along the Long Range Fault and Baie Verte Line in Newfoundland (Fig. 2). The Dunnage is an oceanic terrane as evidenced by abundant ophiolites, mafic volcanics and associated marine sediments (Williams, 1979; Rast and Stringer, 1980; Flagler, 1989). The volcanics and volcaniclastics that overlie the ophiolites are interpreted as an island arc sequence.

In Newfoundland the Gander is in contact to the southeast with the Avalon zone along the Dover and Hermitage Bay faults (Fig. 2). In Cape Breton the contact between the Avalon and Gander zones is not yet firmly established; for example, compare the conflicting interpretations in Rast (1989), Barr and Raeside (1989), and Marillier et al. (1989). Likewise, the Gander/Avalon boundary is not yet resolved in New Brunswick (St. Peter and Fyffe, 1990). It may be at the Wheaton Brook Fault (McCutcheon, 1981b), or the Fredericton Fault (Stockmal et al. , 1987), or the Belleisle Fault (Rast and Stringer, 1974; Nance, 1987).

Williams and Hatcher (1982) interpreted the Avalon zone as a suspect terrane; Rast (1989) believed it to be a collage of blocks which he designated a superterrane. The preponderance of evidence suggests the Avalon accreted to North America (i.e., the Gander zone) in the mid-Paleozoic along a steep transcurrent suture (Marillier et al., 1989). In New Brunswick the Avalon zone is the basement of the Moncton Subbasin (cf. Figs. 2, 3). A summary of the geology and plate tectonic evolution of the Avalon zone in New Brunswick has been given by Nance (1986a, 1987), Bevier and Barr (1990), Bevier et al. (1990), Barr and White (1991a), and Fyffe et al. (1991). Barr and White (1991a) have divided the Avalon zone in southern New Brunswick into two northeast-trending belts separated by a major fault zone.
The more northwestern belt, or Brookville terrane, comprises $900 \mathrm{Ma}$ (?) platformal marbles, quartzites, phyllites, and conglomerates of the Green Head Group and younger paragneiss $(641 \mathrm{Ma})$ and orthogneiss $(605 \mathrm{Ma})$ of the Brookville Gneiss complex. The Brookville terrane is largely concealed and forms the floor of the Moncton Subbasin. The more southeastern belt, or Caledonia terrane, comprises late Precambrian metavolcanic and metasedimentary rocks of the Broad River Group, and felsic and mafic volcanics and clastic continental and marine sedimentary rocks of the Coldbrook Group. The Precambrian rocks of the Caledonia terrane are unconformably overlain by clastics of the Cambro-Ordovician Saint John Group and minor dacite of Ordovician age (Barr et al., 1993). The Brookville and Caledonia terranes are intruded by distinctly different plutonic suites (Barr and White, 1991a). The Caledonia terrane is designated as the Caledonia Uplift on Figures 3 and 4.

The Avalon zone in New Brunswick is characterized by numerous northeast-trending steeply dipping transcurrent faults (Leger, 1986; Leger and Williams, 1986). Ductile dextral movements on the faults have been assigned a Precambrian age by Nance (1987), and an Acadian (Devonian) age by Leger and Williams (1986) and Leger et al. (1988). Regardless of the timing of early ductile displacements, Late Devonian and Carboniferous brittle dextral displacements on the faults controlled the inception(?) and inversion of the Moncton Subbasin.

The Meguma zone is the most southeastern tectonostratigraphic zone in the northeastern Appalachians (Fig. 2 ). It is separated from the Avalon zone along the east-west-trending Cobequid-Chedabucto Fault in northeastern Nova Scotia. The Meguma zone, or terrane of Williams and Hatcher (1982), comprises a generally shallowing-upward se- 


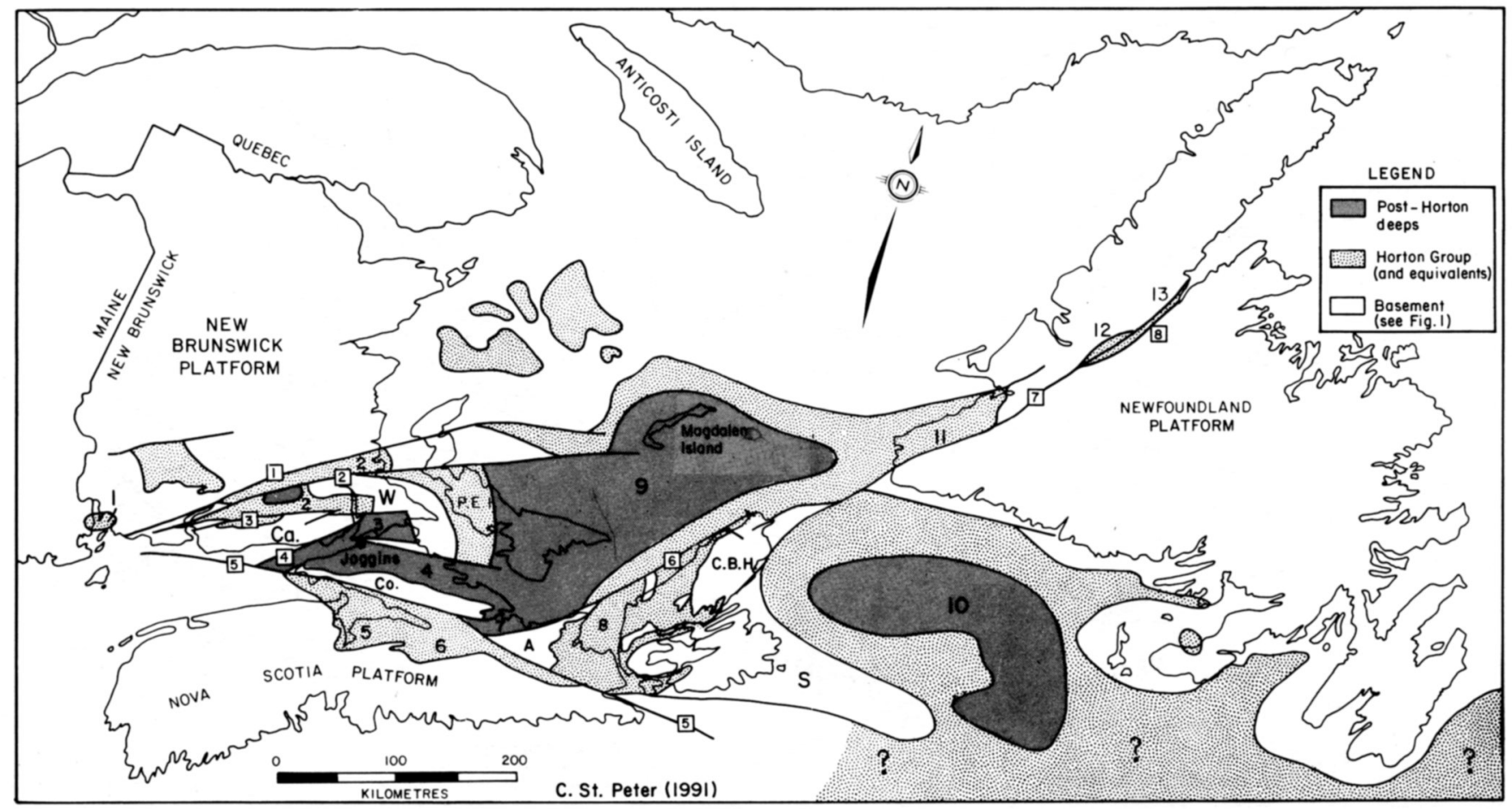

Fig. 3. Map of subbasins and uplifts in Maritimes Basin showing distribution of Horton Group and post-Horton "deeps" where Horton is overlain by thick (Upper Paleozoic) sections. Subbasins: $1=$ Perry; $2=$ Moncton; $3=$ Sackville; $4=$ Cumberland; $5=$ Minas; $6=$ Shubenacadie; $7=$ Stellarton; 8 = Mabou; 9 = Magdalen; $10=$ Sydney; 11 = Bay St. George; 12 = Deer Lake; $13=$ White Bay. Uplifts or Arches: Ca = Caledonia; W = Westmorland; Co = Cobequid; $\mathrm{A}=$ Antigonish; C.B.H. = Cape Breton Highlands; $\mathrm{S}=$ Scatarie. Faults: 1 = Bellisle; $=$ Berry Mills; 3 Clover Hill; $\pi$ = Harvey-Hopewell; $5=$ Cobequid-Chedabucto; $=$ Hollow; $\nabla=$ Long Range; $=$ Hampden. Compled from: Howie and Barss (1974), Wade et al. (1977), Keppie (1979), Fralick and Schenk (1981), Bradley (1982), Hyde (1982), Knight (1983), van de Poll (1983), Martel (1987), Gates (1989), Ryan and Boehner (1990), Ryan et al. (1990a, 1990b, 1990c), Durling and Marillier (1990), McCutcheon (1990), and St. Peter and Fyffe (1990).

quence up to $23 \mathrm{~km}$ thick of Upper Cambrian to Lower Devonian deep water to inner shelf arenites, wackes and lesser grey slates. The Meguma terrane is intruded by Devonian granitoid batholiths.

The Carboniferous strata of the Maritimes Basin are the first overlap assemblage linking the Meguma with the Avalon, implying the Meguma docked with North America in the Late Paleozoic (Williams and Hatcher, 1982; Keppie and Dallmeyer, 1987; Keppie, 1992). The suture zone between the two terranes, the Cobequid-Chedabucto Fault, is a steeply dipping dextral transcurrent structure in Nova Scotia (Eisbacher, 1969). The fault is linked with an imbricate thrust front along the north side of the Bay of Fundy in New Brunswick (Ruitenberg and McCutcheon, 1982; Rast, 1984; Mosher and Rast, 1984; Nance and Warner, 1986; Nance, 1987). Movement on the Meguma-Avalon boundary fault zone during the Late Carboniferous (Variscan orogeny) is reflected by transpressive displacements cutting the Moncton Subbasin sequences. Chevron Canada Resources seismic reflection lines in the Bay of Fundy demonstrate that movement continued on the CobequidChedabucto Fault until at least the Early Jurassic.

\section{MARITIMes BASIN GeOMETRY}

Much work on the Maritimes Basin has been undertaken in the past decade by many geologists. Some of the relevant regional studies include those of Fralick and Schenk (1981), Bradley (1982), Knight (1983), Gibling and Rust (1986), McCutcheon and Robinson (1987), St. Peter (1987), Yeo and Ruixing (sic) (1986), Boehner et al. (1986), and Hamblin (1989, 1992). A generalized summary of the Maritimes Basin has been given by Bradley (1982). He described the basin as a two-part structure, comprising an early strike-slip dominated pull-apart basin with restricted areal extent and centred in the Magdalen Island area of the Gulf of St. Lawrence (Fig. 3), and a later and more widespread second part as a thermal subsidence sag-basin (Reading, 1982). Although this two-part "syn-rift" and "postrift" model has an attractive simplistic appeal, the Maritimes Basin is in fact much more complex than Bradley's model (see, for example, Haszeldine, 1984; Fyffe and Barr, 1986; Boehner et al., 1986; McCutcheon and Robinson, 1987). In particular, the early pre-sag phase is not a single strike-slip transtensional rift but comprises a series of sedimentary subbasins, or their erosional remnants, some of which lie beneath and some outside of the present boundaries of the late sag basin (Fig. 3, cf. Fig. 1).

The shapes of the subbasins comprising the Maritimes Basin range from linear grabens [Moncton Subbasin (St. Peter, 1992a, 1992b)], to half-grabens [Ainslie and Cabot subbasins on Cape Breton Island (Hamblin, 1992)], to rhomboidal [Stellarton Basin in northern mainland Nova Scotia (Yeo, 1985) and Sackville Subbasin in New Brunswick (Fig. 3; Martel, 1987)]. Deposi- 
tional margins are in part preserved in all of these subbasins, except possibly the Sackville Subbasin which is buried by Windsor Group and younger strata (Fig. 3, Table 1).

The subbasins did not all develop simultaneously. Their thickest sedimentary sequences and the time of maximum subsidence range from late Middle Devonian to Westphalian C (Howie and Barss, 1975; Bradley, 1982, table 1). The early sedimentary fill in the subbasins is in many places cut by faults with Carboniferous displacements (Belt, 1968; Webb, 1963, 1969; Fralick and Schenk, 1981; Knight, 1983; and Leger, 1986). Where faults had more than one period of movement, or changes in the sense of displacement, renewed deposition on the footwall blocks resulted in the formation of second generation subbasins (depocentres) over the earlier subbasin. Continued displacement on numerous regional faults (Belt, 1968; Webb, 1969) and consequent translocation of depocentres has resulted in a Maritimes Basin complex comprising in any one place the superposition of one or more generations of sedimentary subbasins (Kelley, 1967; Howie and Barss, 1975; Bradley, 1982).

Three periods of deformation affected the Maritimes Basin during the course of its depositional history. This is evident by regional unconformities or disconformities in the stratigraphic record (Table 1). The structural inversions of the basin fill caused uplift and erosion of parts of the stratigraphic column in many subbasins; consequently the origin and former shapes of some subbasins remain in doubt.

The stratigraphy within the Maritimes Basin has been summarized by Roliff (1962), Kelley (1967), Hacquebard (1972), Howie and Barss $(1974,1975)$, Williams (1974), and van de Poll (1978). Thickness estimates indicate that up to $8 \mathrm{~km}$ of predominantly continental clastic sediments were deposited in the basin. Regionally the stratigraphic section can be divided into five lithostratigraphic groups; in ascending order they are: Horton, Windsor, Mabou, Cumberland, and Pictou (Ryan et al., 1991; Ryan and Boehner, 1990). All five groups are present in the Moncton Subbasin. In New Brunswick, rocks stratigraphically equivalent to the Mabou Group are given the name "Hopewell Group" (Table 1, Fig. 4).

\section{Stratigraphy In Moncton Subbasin}

The Moncton Subbasin is a northeast-trending graben-like depocentre underlying an area of about $3700 \mathrm{~km}^{2}$. The southern margin of the subbasin is defined by the contact with crystalline rocks of the Caledonia Uplift (Fig. 4). This contact is very complex and includes three different unconformities, one each at the base of the Horton, Windsor, and Cumberland groups (Table 1, Fig. 4). In the east the basal Horton and Windsor unconformities are cut by many faults. The northern boundary of the subbasin is delimited by the Kierstead Mountain and Belleisle faults (Fig. 4). In the east the subbasin bifurcates around the Westmorland Uplift, a shallowly buried northeast- to easttrending basement ridge (Fig. 3). Granite of this ridge is exposed in a small inlier near Gaytons (Fig. 4).

The stratigraphic pile in the Moncton Subbasin comprises two early depositional sequences (allocycles), the Horton Group and the Windsor/Hopewell groups. Both allocycles are bound below and above by unconformities (Table 1). The upper allocycle, represented by the Windsor and Hopewell groups is succeeded by regionally distributed fluviatile and paludal strata of the Cumberland and Pictou groups (Table 1).

\section{Allocycle 1 - Horton Group}

The Moncton Subbasin, like most other early-formed depocentres in the Maritimes Basin complex, contains a thick basal section of Horton Group strata. The Horton Group in the Moncton Subbasin is divided into three conformable formations; they are in ascending order: Memramcook Formation, Albert Formation, and Weldon Formation (Table 1), (Norman, 1941; Carter and Pickerill, 1985a; St. Peter, 1992a, 1992b). The Horton lithostratigraphy in a regional sense comprises from the base to the top a three-part coarse-fine-coarse cycle. There are local variations on this scheme, depending upon proximity to source areas, but in general the Memramcook is coarse, the Albert coarse to fine and the Weldon fine to coarse. Each formation is briefly described below.

\section{Lithostratigraphy}

The Memramcook Formation represents the first record of sedimentation in the Moncton Subbasin. The formation comprises mainly red polymictic conglomerate, sandstone, mudstone and minor calcrete. The type section of the Memramcook Formation is along Stony Creek just south of the Gaytons Fault in the southeastern part of the Moncton Subbasin (Fig. 4). The Memramcook Formation is well exposed along the Pollett River south of Elgin (Fig. 5), where it is in fault contact with basement rocks of the Caledonia Uplift. Southwest of the Pollett River, Memramcook strata occur in a narrow outcrop belt lying on basement rocks in the Walker Settlement area and in a broad belt from the Wards Creek Fault to Hampton Station (Fig. 4). To the northwest, the Memramcook is exposed between the Kierstead Mountain and Belleisle faults and in a narrow outcrop belt faulted against the Jordan Mountain basement inlier. Memramcook strata are also exposed in the Indian Mountain area north of Moncton.

The stratigraphy and tectonic history of the Memramcook Formation have been described by Popper (1965). A more recent account of the lithostratigraphy of the formation has been given by Carter and Pickerill (1985a). In the type section at Stony Creek, the Memramcook Formation consists of fining-upward sequences of pebble conglomerate, trough- and tabular cross-bedded gritty sandstone, and mudcracked mudstones with locally abundant caliche nodules. The strata and bedforms suggest a meandering stream environment of deposition.

In the Pollett River, Walker Settlement, Kierstead Mountain, Jordan Mountain and Indian Mountain sections, the Memramcook Formation is predominantly pebble to boulder polymictic conglomerates that range from matrix-supported to clast-supported. The clasts vary from angular to subrounded and are typically set in a mud or muddy sand matrix. The conglomerate sequences contain subordinate interbeds of pebbly mudstones, muddy grits and mudstones. The absence of cross-beds or clast imbrication in the conglomerates or sandstones preclude an assessment of sediment transport vectors in the Memramcook strata in these areas. A decrease in clast size 
Table 1. Lithostratigraphy in the Moncton Subbasin, New Brunswick (modified after St. Peter, 1992a, 1992b).

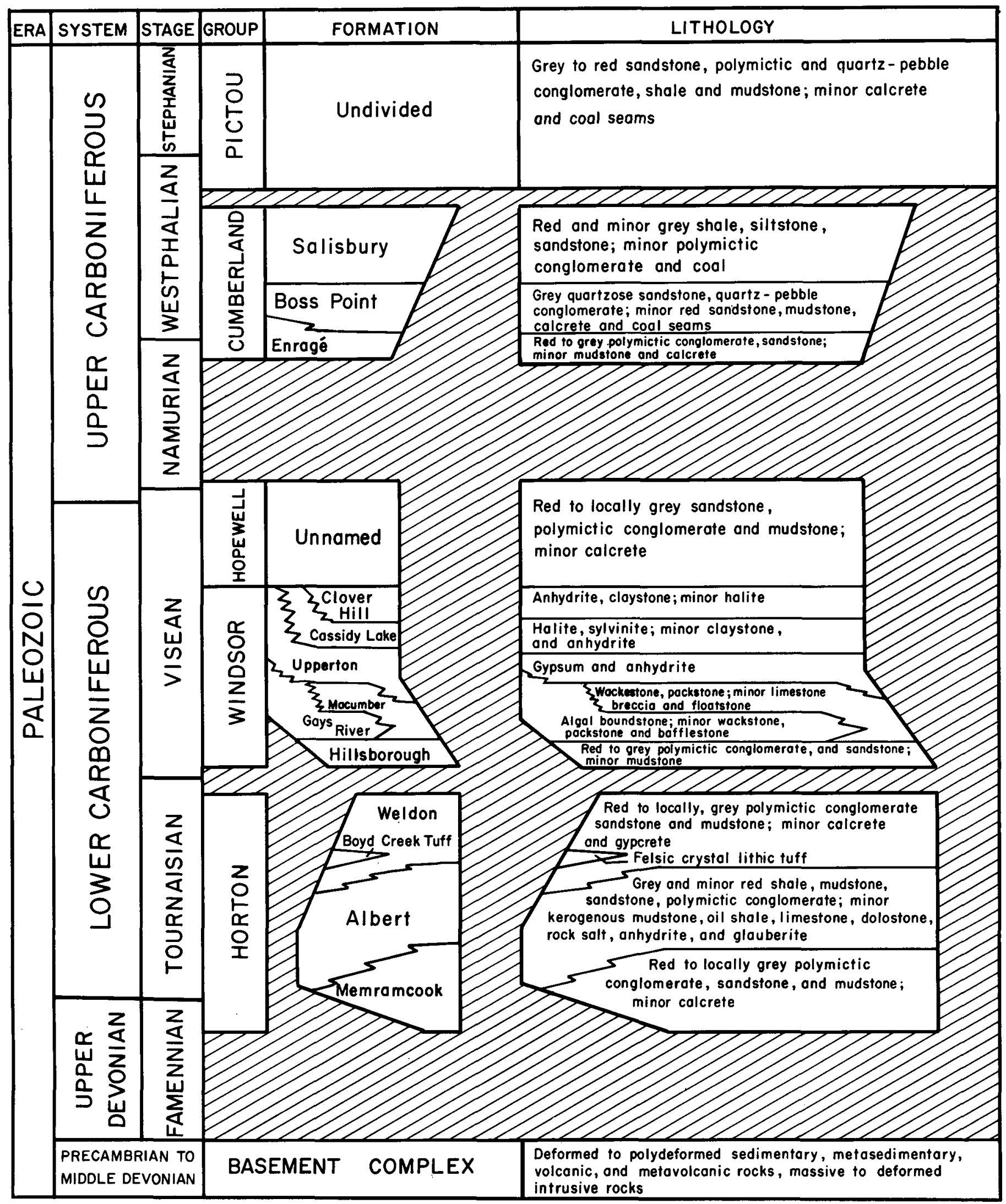

towards the northwest, away from the Caledonia Uplift, was noted in Memramcook conglomerates on the northwest side of the Clover Hill Fault (Fig. 4) (McCutcheon, 1978). In general, the coarse-grained nature of the deposits and the fact that they are typically in fault contact with basement blocks suggest a local source for the detritus. 


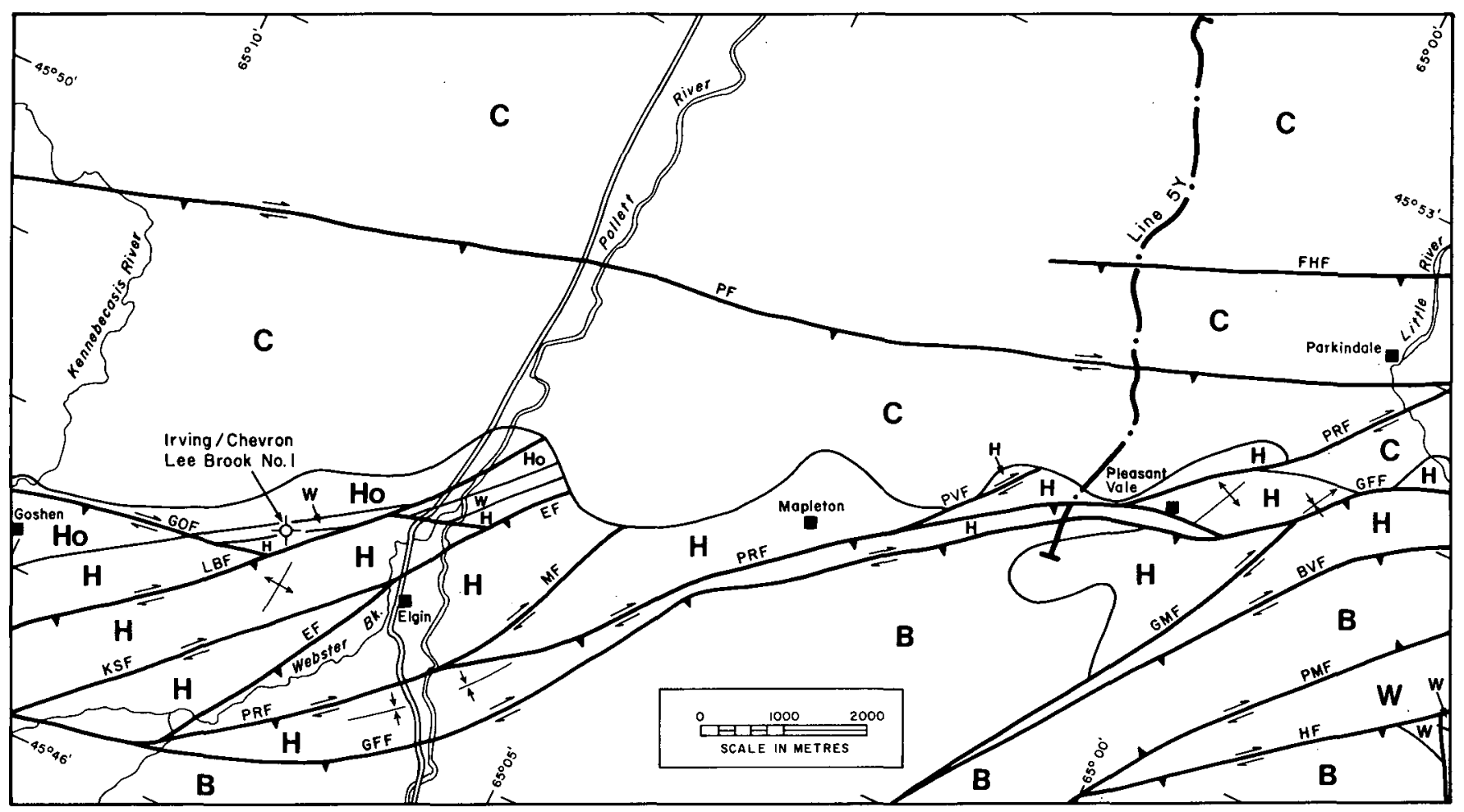

Fig. 5. Simplified geology map of Elgin/Parkindale area. Symbols are the same as on Figure 4. Fault names in alphabetical order: BVF $=$ Belliveau Fault; EF = Elgin Fault; FHF $=$ Forest Hill Fault; GFF $=$ Gordon Falls Fault; GMF = Gowland Mountain Fault; GOF $=$ Goshen Fault; $\mathrm{HF}=$ Hillsborough Fault; KSF $=$ Kay Settlement Fault; LBF $=$ Lee Brook Fault; MF = Mapleton Fault; PF $=$ Parkindale Fault; PMF $=$ Prosser Mountain Fault; PRF = Pollett River Fault; PVF = Pleasant Vale Fault.

The Memramcook beds adjacent to the basement blocks are believed to represent proximal alluvial fan deposits formed by debris flow and braided stream processes (Popper, 1965; Carter and Pickerill, 1985a). However, the character of seismic reflections in the Memramcook away from the basement source areas suggests that the formation in the axial part of the Moncton Subbasin in the subsurface comprises a sequence of regularly interbedded sandstones (or conglomerates) and mudstones (St. Peter, 1992a, 1992b). In other words, most of the subsurface Memramcook is probably similar to the fining-upward sequences seen in the type section.

The Albert Formation has been mapped by Norman (1941), Gussow (1953), Greiner (1962), St. Peter (1982, 1992a, 1992b) and Carter and Pickerill (1985a, 1985b). The formation comprises grey shale, mudstone, sandstone, conglomerate, and minor red shale, kerogenous mudstone, oil shale, limestone, dolostone, rock salt, anhydride, and glauberite. The Albert conformably overlies the Memramcook Formation. Seismic reflection profiles throughout the Moncton Subbasin confirm a conformable relationship between the Memramcook and Albert formations (St. Peter, 1992a, 1992b). Historically, the contact between the two formations has been placed where the predominant red colour of the Memramcook beds gives way to the dominant grey of the Albert (Gussow, 1953). The contact between the Memramcook and Albert formations has been redefined by St. Peter (1992a, 1992b). The boundary is placed, upon ascending the section, where the strata, regardless of colour, give evidence of wave-generated ripples, storm deposits, kerogenous algal laminations, fish skeletons and detritus, ostracods, algal oncolites or algal stromatolites. Further, the Albert Formation is defined to include all beds in the Horton Group which are laterally equivalent to those with the above designated features.

Wright (1922) and Greiner (1962) divided the Albert Formation into three members. Greiner designated the members from oldest to youngest: Dawson Settlement, Frederick Brook, and Hiram Brook. Basin-wide studies in the past fifteen years show that the lithostratigraphy of the Albert Formation is not a simple three-layer pile, but comprises an association of stacked and intertongued lithofacies (Worth, 1977; Pickerill and Carter, 1980; Carter and Pickerill, 1985a, 1985b; St. Peter, 1989, 1992a, 1992b). Six lithofacies have been defined and mapped by St. Peter (1992a, 1992b). They are: (1) conglomerate facies, (2) sandstone facies, (3) mudstone facies, (4) mudstone/sandstone facies, (5) kerogenous mudstone facies, and (6) evaporite facies.

The Albert Formation sediments are predominantly lacustrine deposits associated with upland mudflat and alluvial fan sequences (Greiner, 1977; St. Peter, 1992a, 1992b). Consequently, the sediments display a complex basin-wide lateral transition from coarse-grained, near-source, proximal deposits to finer-grained lacustrine distal deposits. The lithofacies are briefly described below, beginning with the coarse-grained strata and finishing with the fine-grained lacustrine sequences.

The Albert conglomerate facies is mainly restricted to the southern margin of the Moncton Subbasin at the site of several alluvial fans or fan-deltas. The conglomerate occurs at various stratigraphic levels, but is typically most common near or at the base, or as tongues in the upper part of the formation (St. Peter, 
1992a, 1992b). In proximal positions, such as adjacent to the Clover Hill Fault, conglomerate constitutes the entire Albert section.

The conglomerate lithofacies comprises grey to greenish grey and locally red, polymictic conglomerate, fine- to very coarse-grained sandstone, and minor mudstone, kerogenous mudstone, kerogenous shale and limestone.

The conglomerate facies is interpreted as predominantly the product of alluvial fan braided stream deposition, and nearshore lacustrine (fan-delta) deposition. The poor sorting, immature composition, planar cross-bedding, subordinate trough cross-beds, lenticular bedding, cut-and-fill features, and finingupward cycles of lithotypes (Miall, 1978) are all typical characteristics of braided river deposits (Reineck and Singh, 1980; Mathews, 1974; Williams and Rust, 1969; Bull, 1972; Rust, 1979, 1981; Miall, 1985; McPherson et al., 1987). The fact that the conglomerates are largely grain-supported and have very little mud matrix also suggests that the deposits are largely water-laid (Williams and Rust, 1969; Bull, 1972; Rust, 1979).

The conglomerate facies, as seen in outcrop, contains boulders and large cobbles near the Caledonia Uplift. In general, clast size in the conglomerate decreases away from the uplift (McCutcheon, 1978; Pickerill et al., 1985). The presence of abundant sand beds within the conglomerate sequences suggests a probable medial or lower fan depositional environment (Bull, 1972; Link and Osborne, 1978; Rust, 1979, p. 16).

Some of the coarse-grained conglomerates and sandstones were assuredly deposited in a lake. For example, features in associated lithotypes, such as wave ripples in sandstones, kerogenous (algal) laminations in some mudstones and shales, ostracods and fish scales in shales, and algal stromatolites and oncolites in limestones all imply lacustrine deposition (see lacustrine criteria in Picard and High, 1972). Consequently, the close spatial association of the fine-grained lithotypes with the conglomerates strongly suggests that the conglomerate-dominated sections define the locus of lacustrine fan deltas.

The sandstone facies consists of grey, fine- to coarse-grained sandstone, with minor interbeds of mudstone, kerogenous mudstone, limestone, and conglomerate. The sandstone facies is up to $250 \mathrm{~m}$ thick and occurs in the medial part of the Albert Formation, typically overlying the kerogenous mudstone facies (St. Peter, 1992a, 1992b).

The sandstone facies shows evidence of local subaerial and widespread subaqueous deposition; it is implied that sedimentation took place near a lacustrine strand. The position of the sandstones within mudstones and kerogenous mudstones of undoubted lacustrine origin, and the common presence of wave ripples in the sandstones, strongly imply deposition mainly above storm wave base. Paleocurrent data, particularly in the eastern part of the subbasin, are consistent with variably directed storm currents.

The water level of a lake is much more variable than that of the sea (Picard and High, 1972; Link et al., 1985) and is subject to both climatic and tectonic influences. For example, rainfall, inflow, discharge, and evaporation have a fundamental control on water level (Hardie et al., 1978). Tectonic instability with its resulting control on subsidence rates is, however, considered to be the primary control on lake water level in rift and pull-apart basins (Blair, 1987; Blair and Bilodeau, 1988;
Martel, 1990). Consequently, relatively rapid transgressions and regressions of a lake in a syntectonically active basin, such as that envisaged for the Moncton Subbasin, are to be expected. This has been admirably demonstrated, for example, in Late Tertiary to Recent lacustrine strata of the strike-slip Walker Lake Basin of Nevada (Link et al., 1985). Mudstones displaying limestone caliche nodules and mudcracks in close association with sandstone showing wave ripples and storm layers are evidence of common transgressions and regressions in paleolake Albert. Similar fluctuations in lake levels have been documented in correlative Tournaisian lacustrine deposits of the Horton Bluff Formation of Nova Scotia (Hesse and Reading, 1978).

The mudstone/sandstone facies comprises abundant grey mudstone and brown kerogenous mudstone, subordinate feldspathic and lithic sandstone, and minor conglomerate, kerogenous shale, nodular limestone, and oncolitic limestone. The facies is well represented in the subsurface at the Stoney Creek Gas and Oil Field (Fig. 4), where coarsening-upward and fining-upward intervals of sandstone up to and locally greater than $30 \mathrm{~m}$ thick (Howie, 1968) occur within a sequence dominated by mudstone, kerogenous mudstone, shale and kerogenous shale (Greiner, 1962; Howie, 1968; Pickerill et al., 1985; Foley, 1989).

A relatively low energy lacustrine setting for the mudstone/ sandstone facies is indicated by the abundance of grey mudstones, silty parallel-laminated mudstones and brown calcareous and dolomitic kerogenous mudstones. The mudstones and, particularly, the kerogenous mudstones in many places contain rhomboid-shaped, black, vitreous scales of fresh water palaeoniscid fish (Lambe, 1909; Greiner, 1974, 1977). The disarticulation of fish implies higher energy conditions in this environment than in the deep lacustrine setting of kerogenous mudstone facies (see below). Sandstones containing waveformed ripples and cross laminations showing no obvious paleocurrent maxima occur within mudstones of undoubted lacustrine origin (St. Peter, 1992a, 1992b). This implies the sandstones are within-lake beds deposited mainly above storm wave base. In this regard, the fining-upward and coarseningupward/fining-upward sequences seen in well cuttings at Stoney Creek are interpreted as transgressive (i.e., waning energy) and regressive/transgressive cycles, respectively.

The mudstone facies comprises grey and lesser red mudstone and shale with minor interbeds of sandstone, conglomerate, kerogenous mudstone, kerogenous shale, and nodular limestone. Stratigraphically, the mudstone facies occurs only in the basal or medial parts of the Albert Formation between Elgin (Fig. 5) and Turtle Creek (Fig. 6). However, east of Turtle Creek and north of the Boudreau Fault, the Albert Formation changes from dominantly conglomerate and sandstone in the west to mainly mudstone and shale in the east. Consequently, east of Turtle Creek, the mudstone facies occurs not only at the base but also at the top of the formation. The upper mudstones form an elliptical zone around the evaporite facies in the area near Weldon (Figs. 4, 7). In the western part of the Moncton Subbasin mudstones occur mainly in the medial and upper parts of the formation. Mudstones dominate the entire Albert in the belt from Cornhill to Indian Mountain (Fig. 4).

The mudstone facies is interpreted to have been deposited mainly on mudflats near the margin of a lake. Some beds were undoubtedly deposited in "shallow" water within the lake. The 


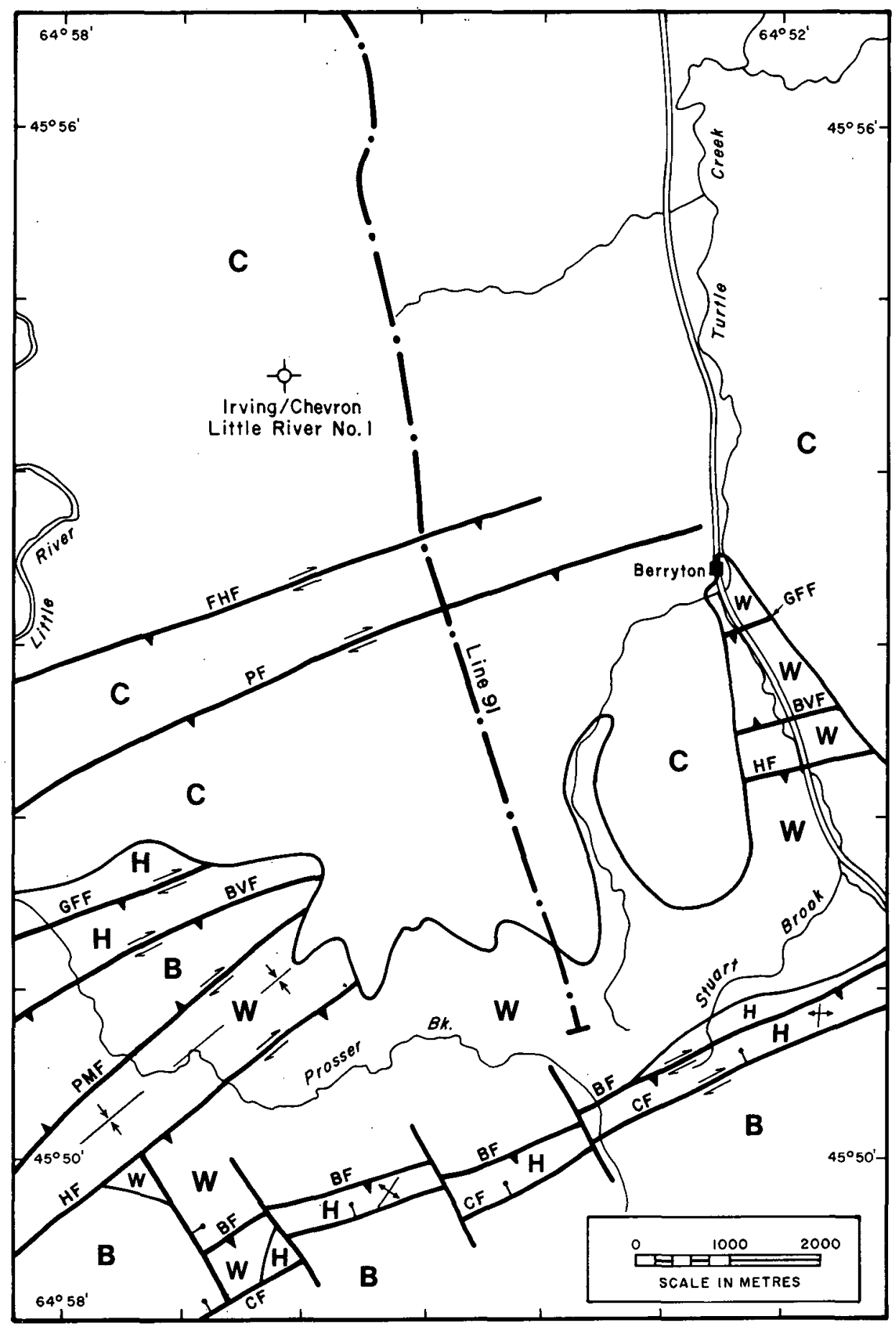

Fig. 6. Simplified geology map of Turtle Creek/Prosser Brook area. Symbols are the same as on Figure 4. Fault names in alphabetical order: BF $=$ Boudreau Fault; BVF $=$ Belliveau Fault; $\mathrm{CF}=$ Caledonia Fault; FHF $=$ Forest Hill Fault; GFF = Gordon Falls Fault; HF $=$ Hillsborough Fault; $\mathrm{PF}=$ Parkindale Fault; PMF $=$ Prosser Mountain Fault.

mudstones in the lowest part of the formation are red and grey, and contain mudcracks and paleosol horizons. This, with the near absence of organic matter preservation (i.e., muds containing kerogen or algal laminae), suggests deposition on mudflats perhaps representing the most distal part of alluvial fans. The intertonguing of fine-grained mudflat and playa deposits with coarse-grained alluvial fan strata is often reported in arid intermontane basins (Bull, 1972; Link and Osborne, 1978; Miall, 1981). Reeves (1970) describes the origin, classification and geologic history of caliche in Texas and New Mexico.
The mudstone facies in the upper part of the Albert Formation near Petitcodiac River interdigitates with evaporite facies. The latter contains beds of glauberite and thick sections of rock salt (Hamilton, 1961; Webb, 1977). Glauberite has been reported from saline mudflat sediments adjacent to a salt pan in the Saline Valley, California (Hardie et al., 1978). This further implies that the Albert mudstone facies was in large part deposited on marginal lacustrine mudflats.

The kerogenous mudstone facies consists of kerogenous shale (oil shale), kerogenous mudstone, shale, mudstone, and minor sandstone, conglomerate, limestone, and dolostone. This 


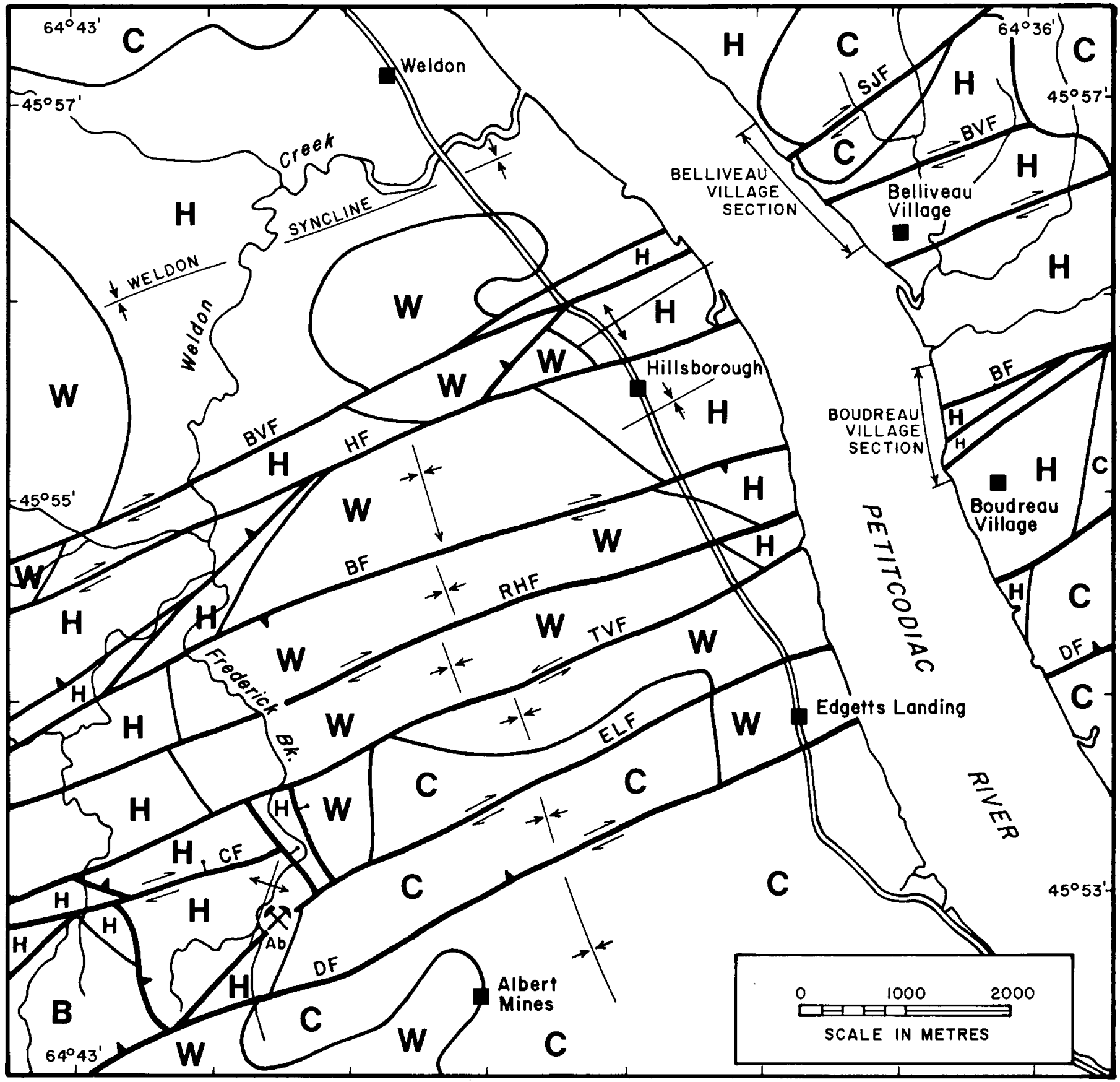

Fig. 7. Simplified geology map of Hillsborough/Albert Mines area. Symbols are the same as on Figure 4. Fault names in alphabetical order: BF $=$ Boudreau Fault; BVF $=$ Belliveau Fault; $C F=$ Caledonia Fault; DF $=$ Dorchester Fault; ELF $=$ Edgetts Landing Fault; HF $=$ Hillsborough Fault; $\mathrm{RHF}=$ Round Hill Fault; SJF $=$ Saint-Joseph Fault; TVF = Taylor Village Fault.

facies is best developed in the southeastern part of the Moncton Subbasin near Rosevale and Saint-Joseph (Fig. 4) and along upper Frederick Brook (Fig. 7). Wright (1922) first noted that the kerogenous mudstone facies lies stratigraphically in the central part of the Albert Formation. Greiner (1962) formally designated these beds as the Frederick Brook Member of the Albert Formation.

The organic matter-rich and organic matter-poor lithotypes comprising kerogenous mudstone facies have been described in great detail by Smith (1985), Smith and Gibling (1987) and Smith et al. (1991). The facies is interpreted as a "shallow" to "deep" lacustrine sequence. The sections dominated by micro- laminated oil shale with well preserved organic laminae and whole fish fossils represent a very low energy, deep anoxic lacustrine environment (Smith, 1985; Smith and Gibling, 1987). Absence of bioturbation in the oil shales suggests an inhospitable environment for benthos. The rhythmic varve-like character of the laminae may indicate a seasonal or other cyclic climatic control on deposition of the deep lacustrine beds.

Widespread synsedimentary folds and local intraformational mudstone and sandstone breccias within the laminated oil shale sections imply considerable bathymetric relief. The mudstone breccias may have formed by slumping. Sandstones with intraformational clasts of laminated oil shale imply a sudden 
violent high energy transport mechanism, again possibly indicating substantial bathymetry. However, the absence of graded bedding or Bouma sequences in the sandstone breccias, seems to rule out a density flow mechanism.

The less organic matter-rich sections, that is, those containing mainly kerogenous laminated mudstone, are interpreted as representing a shallower lake environment than that represented by micro-laminated oil shale facies. The kerogenous laminated mudstones contain more siliciclastic silt and less clay and organic matter than oil shale beds; this implies a shallower water setting (Picard and High, 1972, fig. 8). Interbeds of limestone grainstones and wave ripple-laminated siliciclastic sandstones within kerogenous laminated mudstone intervals indicate deposition above fair weather wave base. Algal laminated limestones, algal oncolites within grainstones, and micritic algal mats within kerogenous mudstones, likewise imply a relatively shallow water environment.

The evaporite lithofacies consists of mostly rock salt and rock salt/carbonate mudstone breccia. There are minor beds of carbonate mudstone containing crystals, nodules, irregular layers and veins of halite, anhydride and glauberite. Significant glauberite beds occur in the upper and lower parts of the facies. Although there are no surface exposures of the evaporites in the Moncton Subbasin, the facies has been intersected in several boreholes on the east and west sides of the Petitcodiac River near Weldon. Evaporites have also been cut in a core hole near Cornhill in the northwestern part of the subbasin (Fig. 4).

The non-siliciclastic minerals comprising the evaporite facies are micritic calcite, gypsum, glauberite, and halite. Cores show that the first evaporite mineral to crystallize was micritic calcite. It is essentially the host rock in which the other minerals subsequently grew. The micrite forms carbonate mudstone beds containing thin parallel laminae of siliciclastic silt and fine-grained sand. Synsedimentary folds in the micrite indicate an early (primary?) origin. It is not clear if the micrite precipitated chemically or biochemically from the lake waters. However, the absence of algal laminae, algal remains, fauna, or bioturbation, and the generally arid and saline conditions inferred from desiccation features and associated salts, nearly preclude a biogenic origin for the micrite. Gypsum and glauberite have both a diagenetic and epigenetic origin. There is no well preserved depositional evidence in cores that either of these minerals precipitated directly from a standing body of water. For example, there are no colour bands or delicate parallel chemical laminae (varves) that would be expected if the minerals were precipitated in a perennial saline lake (Hardie et al., 1978). Textural relationships suggest that the diagenetic gypsum and glauberite formed from saturated brines within the carbonate muds below the sediment/lacustrine water interface or perhaps on a playa [saline mudflat of Hardie et al. (1978)] under arid conditions.

Halite, like the gypsum and glauberite, has in part undergone late dissolution and reprecipitation to form monomineralic coarse-grained veins. Together, the obviously widespread diagenetic and epigenetic formation of halite preclude an assessment of possible primary chemical precipitation.

To conclude, the diagenetic minerals of the evaporite fa- cies are interpreted to have most likely formed by evaporative pumping of groundwater and concomitant crystal growth within carbonate muds on desiccated mudflats bordering an ephemeral or perennial saline lake.

The Weldon Formation is the uppermost formation of the Horton Group in New Brunswick. It conformably overlies the Albert Formation (Norman, 1941; Gussow, 1953; Greiner, 1962; Shroder, 1963; Carter and Pickerill, 1985a; St. Peter, 1992a, 1992b). Norman (1941) introduced the name Weldon Formation to describe the red beds that conformably overlie the Albert Formation. He placed the basal Weldon contact at the base of the first red bed overlying a characteristic Albert lithotype. All later writers have essentially followed Norman's recommendation.

In the southeastern Moncton Subbasin the Weldon Formation contains a tuff 'bed' that ranges in thickness from $35 \mathrm{~m}$, north of Weldon, to about $10 \mathrm{~m}$, north of Rosevale. The tuff, called the Boyd Creek Tuff (St. Peter, 1989), occurs a few tens of metres above the Albert/Weldon contact. It forms a significant time line in this part of the Horton section. The tuff is typically mottled purple, red, and cream colour; it contains crystals of feldspar and quartz 0.1 to $0.3 \mathrm{~mm}$ in size, and abundant accidental fragments of volcanic rock and red shale $1.0 \mathrm{~mm}$ to several centimetres in length (Shroder, 1963).

The most comprehensive description of the distribution and lithology of the Weldon Formation is that given by Shroder (1963). The type area is along Weldon Creek (Fig. 7) in the Hillsborough area (Norman, 1941). The largest exposed section of the Weldon Formation in the southeastern Moncton Subbasin is on the east bank of the Petitcodiac River near Belliveau Village between the Hillsborough and Saint-Joseph faults (Fig. 7).

There is no typical stratigraphic section for the Weldon Formation. In the southeastern part of the subbasin the section typically comprises a coarsening-upward sequence from mudstones and siltstones with caliche nodules in the lower part to interbedded lithic and feldspathic sandstones, grits, and polymictic conglomerates near the top. Along the southern margin of the subbasin, from Elgin west to Hampton Station (Fig. 4), and also along the northern margin between Jordan Mountain and the Belleisle Fault, the Weldon is either entirely coarse-grained polymictic pebble to boulder conglomerate and sandstone or conglomerate at the base fining-upward into mainly red mudstone with minor interbeds of sandstone. In the axial part of the subbasin from Sussex to Indian Mountain, the Weldon Formation is largely red mudstone with minor beds of ripplelaminated sandstone. In general there appears to be a regional decrease in grain size away from both southern and northern basin margins.

Shroder (1963) ascribed the coarse-grained lithofacies of the Weldon Formation to deposition on piedmont alluvial fans. $\mathrm{He}$ interpreted the interbedded shales and currentripple-laminated sandstones along the North River near Fawcett (Fig. 4) as the products of fluviatile deposition. The mudstones and shales with caliche nodules and interbeds of nodular limestone are believed to be largely distal alluvial deposits, possibly in part playa sediments (Shroder, 1963), or overbank fluviatile 
deposits (Carter and Pickerill, 1985a) with locally developed paleosol horizons. The regional distribution of coarse facies along the subbasin margins and fine facies in the subbasin centre supports Shroder's model of marginal alluvial fans and an axial river.

\section{Thickness}

Nowhere in the Moncton Subbasin is a complete unfaulted section of Horton Group rocks exposed, nor has a complete section been drilled. Consequently, the group's thickness and variations in thickness from place to place are poorly known. For example, an incomplete and moderately dipping section of Albert and Weldon strata along North River near Fawcett (Fig. 4) is about $3.5 \mathrm{~km}$ thick. Sonic logs for wells in the Moncton Subbasin show that the velocity for Horton strata is approximately $4000 \mathrm{~m} / \mathrm{sec}$ (St. Peter, unpublished data). Using this velocity, in conjunction with the two-way time from interpreted seismic sections in the southeastern Moncton Subbasin (St. Peter, 1992a, 1992b), suggests a maximum Horton Group thickness of $3.7 \mathrm{~km}$ in the area west of Weldon and about $3.5 \mathrm{~km}$ north of Elgin.

In some places along the southern margin of the Moncton Subbasin and particularly over the Westmorland Uplift, the Horton Group is considerably thinner or absent. The causes for this are: (1) low rates of deposition (condensed sections, such as that at Walker Settlement, Fig. 4), or (2) post-depositional erosion at later unconformities (see below).

\section{Age}

Miospores from the Memramcook Formation near Gaytons in the type area have been dated by D.C. McGregor as probably latest Devonian (locality 6452, reported in Carr, 1968). Elsewhere in the Moncton Subbasin the Memramcook yields early Tournaisian spores (St. Peter, 1992a, 1992b, unpublished data).

The Albert Formation was assigned a Tournaisian age from miospores by Varma (1969). Utting (1987), from a study of miospores in the southeastern part of the subbasin, and by comparisons with the Horton Group of Nova Scotia, assigned the Albert assemblages to the Spelaeotriletes pretiosus-Raistrickia clavata (PC) Spore Zone of Tournaisian, late $\mathrm{Tn} 2$ to early $\mathrm{Tn} 3$, age of western Europe. G. Dolby, consultant palynologist, has recently examined spore assemblages from several localities in the Moncton Subbasin (St. Peter, unpublished data). The results indicate the Albert ranges from early to mid-late Tournaisian in age (Tnlb to middle Tn3 age of western Europe).

The age of the Weldon Formation is bracketed by the late Tournaisian age of the youngest Albert beds and by the mid-Visean age of the basal Windsor Group limestones (Utting, 1980). It is quite likely that the Weldon Formation is entirely late Tournaisian in age. This conclusion is reached by attributing the missing lower Visean time gap, that is, the time prior to deposition of basal Windsor limestones (Utting, 1980), to the pre-Hillsborough hiatus and the period of Hillsborough deposition (Table 1).

\section{Rate of deposition}

The time constraints imposed by the miospores suggest the Horton Group was deposited over a period of about $13 \mathrm{Ma}$. This approximation is arrived at by using a basal Famennian boundary age of $367 \mathrm{Ma}$ and a top Tournaisian boundary of $349.5 \mathrm{Ma}$ (Harland et al., 1982, 1989).

The maximum preserved post-compactional thickness of the Horton Group is between 3.5 and $4.0 \mathrm{~km}$. The original (preerosional) thickness may have been $5 \mathrm{~km}$ or more. The thickness and time data suggest a depositional rate of about $30 \mathrm{~cm}$ per thousand years (Fig. 8). Rates of this magnitude are consistent with the lower values quoted for continental rifts or pullapart basins (Link and Osborne, 1978; Stoffers and Hecky, 1978; Reading, 1982; Martel, 1990). The data therefore suggest, but do not validate, a continental rift or wrench setting for the Moncton Subbasin during the Horton allocycle.

\section{Unconformity $V_{1}$}

The Horton tectonic cycle closed in late Tournaisian time with the resultant inversion of the Moncton Subbasin. Evidence of the tectonism includes: (1) reactivation of basin-margin faults, (2) formation of new faults that deform the Horton section but pre-date the Windsor Group, (3) generation of macroscopic and mesoscopic folds in Horton strata with axes typically oblique to strike-slip fault traces, (4) formation of intra-basinal arches, that are evidenced, for example, by the exposed basement rocks at Gaytons, Jordan Mountain, and Indian Mountain (Fig. 4), and (5) a major period of erosion particularly over rising arches where, in places, the entire Horton Group has been removed; for example, over the Westmorland Uplift. Further details are given below under TECTONIC SETTING.

\section{Allocycle 2 - Windsor and Hopewell groups}

Renewed deposition following the late Tournaisian deformation shows that the Moncton Subbasin, along with other component subbasins of the Maritimes Basin, began to subside. This second depositional sequence in the subbasin, like the preceding Horton Group, is a coarse-fine-coarse allocycle. Unlike the Horton however, the fine-grained rocks of the second allocycle comprise a marine sequence, the only marine rocks in the Moncton Subbasin. The second allocycle consists of the Windsor and Hopewell groups, which comprise in ascending order: basal coarse continental clastics, medial marine carbonates, sulphates, and chlorides and upper fine to coarse continental clastics.

\section{Lithostratigraphy}

The Windsor Group comprises in ascending order the Hillsborough, Gays River, Macumber, Upperton, Cassidy Lake and Clover Hill formations (Table 1). The Hopewell Group has not been subdivided in most of the Moncton Subbasin. Anderle et al. (1979) have defined an informal Hopewell Group stratigraphy in the Marchbank Syncline in the southwest part of the subbasin (Fig. 4). The lithostratigraphy of the Windsor and Hopewell groups is briefly described below. 


\section{SUBSIDENCE / UPLIFT (INVERSION) CURVE FOR MONCTON SUBBASIN}

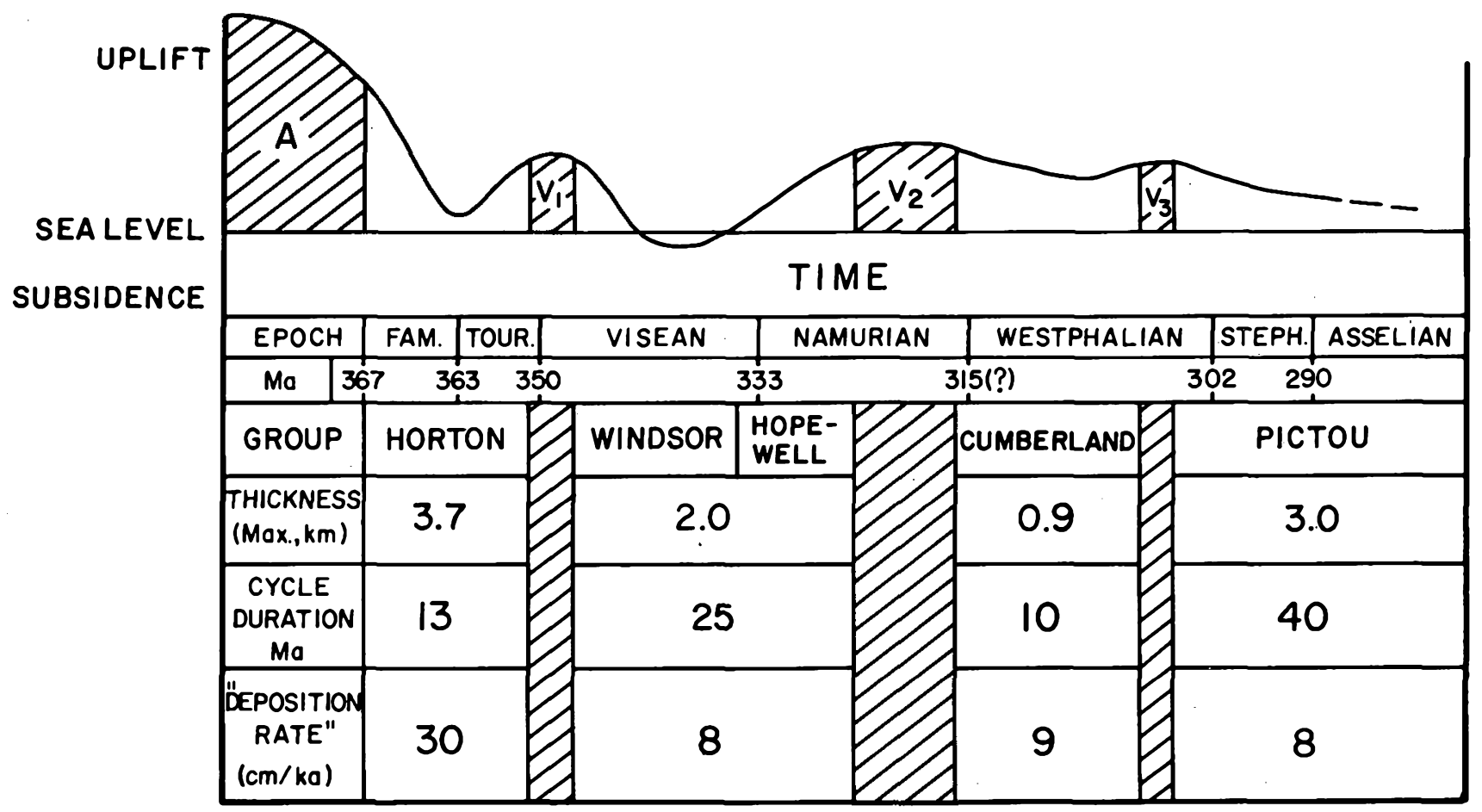

Fig. 8. Subsidence/Uplift (Inversion) curve for Moncton Subbasin. Diagonally ruled pattern represents unconformities or disconformities); $A=$ Acadian, $\mathrm{V}_{1}, \mathrm{~V}_{2}, \mathrm{~V}_{3}=$ Variscan phases. Data from: Howie and Cumming (1963), Harland et al. (1982), McCutcheon (1985), Moore (1985), Ryan et al. (1991), and St. Peter (1992a, 1992b).

The Hillsborough Formation comprises mainly red conglomerate, grit and sandstone with minor mudstone. As the basal formation of the Windsor Group, it rests with angular unconformity on deformed Horton Group strata (see Figs. 9a,b,c and $10 \mathrm{a}, \mathrm{b}$ below under TECTONIC SETTING), or locally along the southern margin of the Moncton Subbasin, oversteps the Horton and lies directly on basement (Figs. 4, 6). The upper Hillsborough contact is conformable with overlying marine Windsor carbonates (Norman, 1941; Gussow, 1953; McCutcheon, 1981a). The contact relationships with underlying and overlying rocks led St. Peter (1992a, 1992b) to assign the Hillsborough Formation to the Windsor Group (cf. Norman, 1941; Kelley, 1967; McCutcheon, 1981a), because it is quite obviously the initial part of the Windsor depositional cycle (Shroder, 1963, p. 74).

The Hillsborough Formation is widely distributed (Gussow, 1953; Shroder, 1963). The formation is thickest ( $400 \mathrm{~m})$ in the belt between Sussex and Havelock (Fig. 4) (St. Peter, 1992a, 1992b). Conglomerate beds form prominent bluffs between Walker Settlement and Sussex (Fig. 4).

A detailed study of Hillsborough Formation lithostratigraphy and sedimentology has yet to be undertaken. Gussow (1953) and Shroder (1963) provide the only regional syntheses. The coarse conglomerates and grits of the formation are typically poorly sorted and comprise polymictic granules to boulders set in a sandy or muddy sand matrix.

The author's observations on a typical Hillsborough exposure northwest of Sussex indicate that the conglomerates and grits occur in thick beds or amalgamated beds with erosional contacts or channels into more thinly interbedded sandstones and mudstones. Both conglomerates and grits are commonly grain-supported and have tabular cross beds. Red mudstone beds are uncommon and show irregular calcite nodules (caliche layers), mudcracks, and rare rain prints. The sandstone and mudstone beds tend to be lenticular as a result of cut-and-fill by the coarser lithotypes.

The compositions, textures, primary structures, and bed forms of the exposed sections of the Hillsborough Formation suggest deposition primarily via braided streams perhaps in the medial parts of alluvial fans (Bull, 1972; Link and Osborne, 1978; Rust and Koster, 1984; Soegaard, 1990).

The Gays River Formation comprises shallow water algal boundstone-buildups or reefs with minor interbeds of bioclastic wackestone and packstone. Locally there are numerous brachiopods, pelecypods, foraminifera and rare gastropods (Gussow, 1953; Globensky, 1970; McCutcheon, 1981a). The Gays River is a basin-fringing or platformal marine lithofacies restricted to the southern and northeastern margins of the subbasin (McCutcheon, 1981a).

The basin-margin marine strata in the western part of the Moncton Subbasin contain abundant siliciclastic sandstone and mudstone interstratified with typical Gays River carbonate lithotypes. McCutcheon (1981a) has assigned these mixed clastics and carbonates the name Parleevile Formation.

The Macumber Formation occurs in the axial part of the Moncton Subbasin and is a basinward sublittoral facies of the Gays River Formation (McCutcheon, 1981a). Accordingly, in the axial parts of the subbasin the Macumber overlies the 
Hillsborough Formation. The Macumber comprises thinly interlaminated wackestone and packstone; intraclasts and pelletoids are common, but fossils are rare. Intraformational breccia (floatstone) is generally present near the contact with the Gays River Formation. Syn-sedimentary slump (gravity) folds are locally common in the Macumber Formation. The folds imply considerable bathymetric relief or tectonic instability in the subbasin.

The Upperton Formation conformably overlies or is intercalated with the upper Macumber. It may be laterally equivalent to the upper Gays River beds (McCutcheon, 1981a). The Upperton occurs in the axial part of the Moncton Subbasin. It consists of stratiform displacive and replacive anhydride, locally seen in a host of mudstone or Macumber-type limestone. In surface exposures the anhydride is largely gypsified. McCutcheon (1981a) interprets a deep water origin for the Upperton Formation.

The Cassidy Lake Formation conformably overlies the Upperton Formation. It is not exposed at surface, but is known from boreholes and two underground potash mines in the Sussex area (Fig. 4). At the Potacan Mining Company mine near Cassidy Lake southwest of Sussex, the Cassidy Lake Formation has been divided into four members: basal halite, middle halite, potash, and upper halite (Anderle et al., 1979; Waugh and Urquhart, 1985). The upper halite member is heterogenous: it contains red sylvinite beds, claystone and anhydride laminae, and a borate mineral assemblage (Roulston and Waugh, 1981; Waugh and Urquhart, 1985). The chlorides and borates suggest restricted circulation and intense evaporation at the close of the marine Windsor cycle in the Moncton Subbasin.

The Clover Hill Formation is known only from boreholes and the two underground potash mines. The formation comprises a lower anhydride and an upper grey-green claystone. At the Potash Company of Saskatchewan mine, east of Sussex, the anhydride and claystone are separated by halite (McCutcheon, 1981a; Waugh and Urquhart, 1985). The basal anhydride is commonly brecciated and the lower contact is disconformable with the underlying salt of the Cassidy Lake Formation, suggesting suberosion of the salt beds. The upper claystone contact is conformable with the continental red clastics of the Hopewell Group. The transitional position of the Clover Hill Formation implies a marine to brackish environment of deposition.

Like the Cassidy Lake Formation, the Clover Hill Formation only occurs in the axial part of the Moncton Subbasin. In contrast, along the margins of the subbasin the uppermost transitional Windsor rocks comprise interbedded carbonates and siliciclastics (i.e., "Samp Hill beds" of McCutcheon, 1981a, p. 189).

The Hopewell Group occurs only in the southwestern part of the Moncton Subbasin. It has been eroded in the eastern end of the subbasin (Fig. 4). The group has been divided into lithostratigraphic units only in the Marchbank Syncline, near the Potacan Mining Company mine, southwest of Walker Settlement. There, Anderle et al. (1979) subdivided the Hopewell Group from the base upward into the Poodiac, Wanamaker, and Scoodic Brook formations. Their subdivision is regarded as informal in that type or reference sections for the formations were not designated, nor were the sedimentology, contacts or ages of the formations described or discussed in any detail.
Anderle et al. (1979) did demonstrate however the complexity in Hopewell stratigraphy. For example, the Poodiac formation comprises red to grey mudstones and sandstones with minor conglomerate interbeds. The Wanamaker is dominantly coarse polymictic conglomerate and sandstone, while the Scoodic Brook is mostly red mudstone, siltstone and finergrained sandstones. Outside the area of the Potacan mine in the Marchbank Syncline, preliminary outcrop evidence indicates a major lithofacies change from nearly entirely coarse-grained Hopewell in the northeast (McCutcheon, 1978) to predominantly mud rocks in the southwest. Thus, the Hopewell Group is essentially coarse-grained along the proximal southern part of the subbasin and largely fine-grained in the distal axial part of the subbasin. It would seem from this that the group represents a series of alluvial fans or a braid plane in proximal locations grading into distal alluvial mud flats or perhaps fine-grained fluviatile strata in the central part of the subbasin.

\section{Thickness}

The total preserved thickness of the Windsor/Hopewell allocycle in the axial part of the Marchbank Syncline is about $1.5 \mathrm{~km}$. This is based on thirteen exploration drill holes at the Potacan Mining Company mine, unpublished seismic reflection profile interpretations, and extrapolations of surface thicknesses for the Hillsborough, Macumber and Upperton formations from the south margin of the syncline. It is believed that the upper part of the Hopewell section in the Marchbank Syncline was eroded prior to deposition of the Cumberland Group.

In the central part of the Moncton Subbasin, northwest of Elgin (Fig. 4), the Windsor/Hopewell cycle is about $2 \mathrm{~km}$ thick based on my interpretation of Chevron Canada Resources Limited seismic profile L29Y (St. Peter, 1992a, 1992b).

\section{Age}

Bell (1929) divided the Windsor Group into five macrofaunal subzones (A, B, C, D, and E) of middle to late Visean age. Only subzone A fauna occur in the Windsor in the Moncton Subbasin (McCutcheon, 1981a). Selective samples collected for miospores by McCutcheon (1981a) from the basal Windsor to the basal Hopewell strata give an assemblage-zone 1 (middle Visean) age. Utting (1980) suggested a possible late Arundian age for the basal Windsor beds (i.e., base of assemblage-zone 1). Comparing Utting's assignment with the Carboniferous time chart in Harland et al. (1989, fig. 3.6a), gives a date of about $344 \mathrm{Ma}$ for the base of the marine Windsor section. The terrestrial Hillsborough Formation has yielded no spores, but may be about $345 \mathrm{Ma}$.

The age of the Hopewell Group is poorly constrained. Mudstones at the base of the group $15 \mathrm{~km}$ southwest of Sussex indicate a miospore assemblage-zone 1 (middle Visean) age similar to the subjacent Windsor (McCutcheon, 1978). Gussow (1953) records the presence of plant fossils Sphenopteridium dawsoni, Telangium affine and Asterocalamites scrobiculatus in Hopewell Group (Shepody Formation) strata in the Cumberland Subbasin. Bell (1944) considered these flora a very early Namurian assemblage.

The upper part of the Hopewell Group is undated in the 
Moncton Subbasin. Unconformably or disconformably overlying rocks of the Boss Point Formation of the Cumberland Group range from late Namurian to Westphalian $A$ in southeastern New Brunswick and northern Nova Scotia (Browne, 1990; Ryan et al., 1991).

The angular unconformity or disconformity at the base of the Cumberland Group suggests a substantial part of the Hopewell Group is missing and that a significant hiatus occurred in the middle to late Namurian. The spore and floral data are tentative, but suggest the Windsor/Hopewell allocycle spanned a period of perhaps $25 \mathrm{Ma}$ (Fig. 8). (See geochronology in Harland et al., 1989, fig. 3.6a.)

\section{Rate of deposition}

Using a maximum measured thickness for the Windsor/ Hopewell allocycle of $2 \mathrm{~km}$ and a cycle duration of $25 \mathrm{Ma}$ gives a post-compaction and lithification depositional rate of $8 \mathrm{~cm}$ per thousand years (Fig. 8). This is about three to four times greater than the rates for stable cratonic sag basins (Reading, 1982), but lower than rates normally encountered in rifts or pull-aparts (Link and Osbourne, 1978; Stoffers and Hecky, 1978; Reading, 1982; Martel, 1990). The decreased rate of deposition compared to the Horton allocycle implies a reduced influence of fault-induced subsidence during the Windsor/Hopewell allocycle.

\section{Unconformity $V_{2}$}

The Moncton Subbasin ceased acting as an independent depocentre in the Namurian with the closing of the Windsor/ Hopewell allocycle. The disconformity or angular unconformity at the base of the overlying Cumberland Group is evident on industry seismic reflection profiles (see Figs. 9a,b,c and 10a,b below under Tectonic SeTting and St. Peter, 1992a, 1992b), and in the eastern end of the subbasin by the absence of Hopewell and upper Windsor strata.

\section{Cumberland Group}

The late Namurian to Westphalian C strata in New Brunswick were first assigned to the Cumberland Group by St. Peter (1992a, 1992b), based on regional correlation with the redefined Cumberland Group of northern Nova Scotia (Ryan et al., 1991). In New Brunswick the Cumberland Group consists of (in ascending order): the Enragé, Boss Point and Salisbury formations.

\section{Lithostratigraphy}

The Enragé Formation unconformably overlies older Carboniferous strata and locally oversteps onto basement. This is particularly evident in the eastern end of the Moncton Subbasin; for example, near Gaytons (Fig. 4), where the Enragé lies on the Horton Group and crystalline rocks of the Westmorland Uplift.

Descriptions of the Enragé Formation have been given by Norman (1941), Gussow (1953), and McLeod (1980). The for- mation is a red bed unit comprising mainly poorly sorted, angular to subangular clast, polymictic conglomerate with lenticular interbeds of flaggy and cross-bedded sandstone (McLeod, 1980). In the eastern part of the Moncton Subbasin the upper part of the Enragé is dominantly a fine-grained facies comprising red sandstone, siltstone and mudstone with common green reduction spheres and locally caliche. McLeod (1980, fig. 9) interprets the Enragé as proximal alluvial fan deposits adjacent to the Caledonian Uplift (Fig. 4) and fluvial channel and overbank deposits to the east and away from the uplift.

The Boss Point Formation conformably overlies the Enragé Formation. It is widely distributed in southern New Brunswick (Ball et al., 1981) and northern Nova Scotia (Browne, 1990). The Boss Point comprises mostly buff or light grey mature quartzose sandstone and quartz pebble conglomerate with subordinate lithic and feldspathic sandstones and mudstones, and minor coaly shale, coal, paloesols and limestone (Browne, 1990). The Boss Point Formation has been interpreted as the deposits of a meandering fluvial system as evidenced from channelling, trough cross-beds and fining-upward sequences (Belt, 1968; Plint and van de Poll, 1984). Browne (1990), however, provides convincing evidence based on composition and bedforms that the Boss Point represents a sandy braided river system with a not too distant source (cf. van de Poll, 1970; Gibling et al., 1991).

The Salisbury Formation was first mapped by Gussow (1953) to define the predominantly fine-grained red beds which gradationally overlie the Boss Point strata in the northeastern part of the Moncton Subbasin from Dunsinane to Moncton (Fig. 4). There is a debate whether the Salisbury Formation occurs on the Maringouin Peninsula on the eastern side of Shepody Bay (Fig. 4). The red bed sequence that unconformably overlies the Boss Point Formation there and which Gussow (1953) correlated with the Salisbury Formation is believed to be more appropriately assigned to the Pictou Group based on contact relationships and regional correlations. A definitive conclusion on this point can not be drawn without further study.

The Salisbury Formation comprises mainly red shale and siltstone, and lesser red to grey arkosic sandstone and poorly sorted polymictic conglomerate. There are locally narrow seams of coal and black shale. The sandstones display cross beds and ripple marks, while desiccation cracks are locally present in the mud rocks.

Previous workers have not interpreted an environment of deposition for the Salisbury Formation. The formation has not been studied by the author. The lithologic content and recorded bedforms suggest a fluvial, probably largely overbank setting with scattered peat swamps.

\section{Thickness}

The Cumberland Group is about $900 \mathrm{~m}$ thick near Salisbury in the axial part of the Moncton Subbasin. This thickness estimate is based on an interpretation of Chevron Canada Resources seismic reflection line 91 (see Figs. 9a,b,c and 10a,b below under Tectonic setring and St. Peter, 1992a, 1992b) and assumes an average sonic velocity of $4000 \mathrm{~m} / \mathrm{sec}$ for the Cumberland strata. The upper part of the Salisbury Formation is eroded in 
the Salisbury area (Fig. 4), and therefore the original maximum depositional thickness of the Cumberland Group is unknown.

Age

No spores have been reported from the Enragé Formation in the Moncton Subbasin, and therefore the age of the base of the Cumberland Group is uncertain. The Boss Point has been dated as late Namurian to middle Westphalian A in northern Nova Scotia (Browne, 1990; Ryan et al., 1991). A Namurian B date given by McLeod (1980) for the Boss Point in New Brunswick is believed to be too old and may represent reworked spores from pre-existing Hopewell Group beds. Similarly, old (Visean) palynomorphs have been eroded and incorporated into the Boss Point in Nova Scotia (Browne, 1990). The Salisbury Formation has been dated recently by G. Dolby as late Westphalian B from a spore-bearing coal seam near Salisbury (St. Peter, unpublished data). The dated coal seam refutes two arguments: (1) that Westphalian B strata are absent in southern New Brunswick, and (2) that there is a disconformity between the Boss Point and Salisbury formations (cf. Gussow, 1953; Carr, 1968).

The uppermost Cumberland Group rocks in southern New Brunswick are early Westphalian $\mathrm{C}$ in age (see miospore data in Ball et al., 1981). The Westphalian D and Stephanian strata that Carr (1968) included in the Salisbury Formation have been reassigned to the overlying Pictou Group (cf. Carr's fig. 2 with Fig. 4 of this paper).

\section{Rate of deposition}

The geochronology given in Harland et al. $(1982,1989)$ suggests a duration of about $10 \mathrm{Ma}$ from the Late Namurian ( $317 \mathrm{Ma})$ through early Westphalian C ( $307 \mathrm{Ma})$. A depositional rate of $9 \mathrm{~cm}$ per thousand years for the Cumberland Group (Fig. 8) is indicated when using a period of $10 \mathrm{Ma}$ and a maximum post-compaction and lithification thickness of $900 \mathrm{~m}$. Comparing this with a rate of $30 \mathrm{~cm}$ per thousand years for the Horton allocycle clearly shows the reduced rate of deposition, and by implication subsidence, from the early to the late history of the Maritimes Basin in southern New Brunswick.

\section{Unconformity $V_{3}$}

In northern Nova Scotia the Pictou Group overlies older Maritimes Basin strata or basement rocks with disconformity, paraconformity, angular unconformity or nonconformity (Ryan et al., 1991). The contact relationship between Pictou Group and pre-existing rocks in New Brunswick is not yet well established largely because the presence of the Cumberland Group in New Brunswick has previously been in doubt. It is interpreted however that the Pictou Group in New Brunswick, like in Nova Scotia, overlies older Maritimes Basin strata with disconformity or unconformity. Gussow (1953, p. 1755 and fig. 5) records a pronounced unconformity between the Pictou Group and Boss Point Formation on the east side of Shepody Bay (Fig. 4). Gussow's interpretation of the contact relationship in this area is believed to be in error; for example, an examination of published maps and Irving/Chevron seismic reflection profiles suggest the map pattern Gussow interpreted as an unconformity is in fact a result of faults that are splays off the Harvey-Hopewell Fault system (St. Peter, unpublished data). Regardless of this problem, the presence of late Namurian-age Boss Point strata closely adjacent to Westphalian D Pictou beds in the Moncton area is taken as evidence of a significant hiatus (see spore assemblages in Carr, 1968). The present data (Gussow, 1953; Carr, 1968; Ball et al., 1981) indicate that the unconformity is of short duration and about middle Westphalian $\mathrm{C}$ in age (Table 1 , Fig. 8).

\section{Pictou Group}

The Pictou Group represents the youngest sequence of strata in the Maritimes Basin in New Brunswick. It is exposed from Shepody Bay in the southeast to the New Brunswick Platform in the northwest (Fig. 4). Gussow (1953) divided the Pictou Group in New Brunswick (from the base upward) into the Salisbury, Scoudouc, Richibucto and Tormentine formations. As noted above, the Salisbury Formation is conformable with the Boss Point and is therefore included in the Cumberland Group. Carr (1968) argued that the geological evidence Gussow (1953) advanced for introducing the Scoudouc Formation was untenable and therefore recommended abandoning the name Scoudouc. Carr's observations are followed here and accordingly the lower fine-grained red beds of the former Scoudouc are included in the Salisbury. The upper coarser strata of the Scoudouc are placed in the undivided Pictou Group. It is not presently possible to demonstrate whether Gussow's Richibucto and Tormentine formations are regionally mappable units everywhere in the Pictou of New Brunswick (cf. van de Poll, 1970; Ball et al., 1981).

The red beds on Prince Edward Island that have historically been included in the Pictou Group (Howie and Cumming, 1963; Hacquebard, 1972; Howie and Barss, 1975; van de Poll, 1983) were reassigned to the new Prince Edward Island Group by van de Poll (1989). The Prince Edward Island Group gradationally overlies the Pictou Group and comprises five finingupward red bed megacyclic sequences to which van de Poll (1989) assigned formation names.

In northern Nova Scotia Ryan et al. (1991) divided the Pictou Group in the type section along River John and elsewhere in the Cumberland Subbasin into three formations. From the base up the formations are: Balfron, Tatamagouche, and Cape John. It is apparent by comparing figure 6 of Gussow (1953) with figure 2 of Ryan et al. (1991) that the latter authors have assigned Gussow's upper Pictou Group strata (Tormentine Formation) to the basal Pictou Group (Balfron Formation) of their usage. Clearly, additional work is required to reconcile the stratigraphic problems in the Pictou Group of New Brunswick. For now the strata are left undivided (Table 1).

\section{Lithology}

The Pictou Group in New Brunswick comprises intervals dominated by buff to grey or red sandstones interstratified with 
intervals dominated by red or locally grey-green mudrocks. The sand-dominated intervals are up to tens of metres thick and typically contain parallel and trough cross-bedded sandstones. The sands contain abundant quartz and subordinate rock fragments and feldspar in a silty and/or calcareous matrix (van de Poll, 1970; Ball et al., 1981).

Conglomerate in thin to thick normally graded or crossstratified beds are common near or at the base of sand-dominated intervals. The conglomerates comprise two types: roundstone polymictic pebble beds and intraformational mudclast beds (Ball et al., 1981).

The conglomerate and sand intervals typically fine-upward and in places several repetitions of conglomerate and sand are present, thus forming multi-story coarse intervals (van de Poll, 1970; Ball et al., 1981). The coarse intervals have been interpreted as meandering(?) stream channel fill and point bar deposits (Ball et al., 1981).

The mud-dominated intervals of the Pictou Group range from thin beds up to sections several tens of metres thick. The mudstones in places show desiccation cracks and pisolitic ferricretes (van de Poll, 1970). Calcareous paleosols (limestone caliche) are also quite common. Thin beds of ripple or parallellaminated sandstones are locally present in the mud intervals. An interchannel floodplain environment containing crevasse splay sands has been postulated for the mud-dominated sequences (Ball et al., 1981, p. 36).

Thin (non-commercial) lenticular seams of coal are locally seen in the Pictou Group. The coal is typically associated with grey carbonaceous to non-carbonaceous siltstone or shale. Stratigraphically the coal appears to lie in the transitional zone between major sand- and mud-dominated intervals (van de Poll, 1970, p. 78)

\section{Thickness}

The Pictou Group, where the name is used in the historical sense to include the red beds of Prince Edward Island, is estimated to be greater than $3000 \mathrm{~m}$ thick in eastern PEI (Howie and Cumming, 1963; Howie and Barss, 1975). A thickness of greater than $3100 \mathrm{~m}$ is calculated from the estimates given by van de Poll (1989) for the five red bed formations on PEI. It is implied from van de Poll's data that the entire Pictou Group may be greater than $3000 \mathrm{~m}$, but it seems unlikely that the thickness much exceeds this in any one area (Hacquebard, 1972; Ryan et al., 1991).

Age

Ryan et al. (1991) give an age of Westphalian D to Early Permian for the revised Pictou Group of Nova Scotia. The criteria employed by Ryan et al. (1991) for distinguishing the Cumberland Group from the Pictou Group in Nova Scotia have been utilized to subdivide the groups in New Brunswick (St. Peter, unpublished data). The tentative results of this subdivision suggest the basal strata of the Pictou Group are late Westphalian $C$ in age (Torispora zone of Barss and Hacquebard, 1967). The youngest dated Pictou Group rocks are those of Prince Edward Island which have yielded spores of Stephanian to Sakmarian (Early Permian) age (van de Poll, 1989).

\section{Rate of deposition}

The geochronology for the Carboniferous and Permian periods given in Harland et al. (1989) indicates that the time span from late Westphalian C through Sakmarian encompasses about 40 million years. This would imply that the $3000 \mathrm{~m}$ of Pictou Group strata had an average post-compaction depositional rate of about $8 \mathrm{~cm}$ per thousand years (Fig. 8). Therefore, the rate of sediment accumulation during the Pictou cycle was approximately the same as that during the preceding Windsor/Hopewell and Cumberland depositional cycles (Fig. 8), suggesting a continuance of the more stable or passive tectonic regime established following the Horton allocycle.

\section{Paleoclimate}

The large-scale (several tens to hundreds of metres) vertical cyclicity of alternating coarse and fine lithofacies in alluvial foreland, rift and pull-apart basins is generally attributed to tectonic causes (Blair and Bilodeau, 1988). Therefore, the largescale, long period (millions of years) Horton and Windsor/ Hopewell allocycles in the Moncton Subbasin are likewise interpreted as primarily resulting from fault-related subsidence and uplift (see below under Tectonic setTING). Paleoclimate is believed to have had an important but secondary influence on the thinner, short period (thousands of years) cycles in the basin fill.

During the Late Devonian and Carboniferous the Maritimes Basin was situated at a paleolatitude of 10 to $15^{\circ} \mathrm{S}$ (Morel and Irving, 1978). Therefore, in a regional sense the paleoclimate should have been hot and depending on rainfall amounts either arid, semiarid or humid. The basin and range paleotopography envisaged for the early history of the Maritimes Basin would probably have resulted in local orographic effects. Consequently, there may have been considerable differences in paleoclimate (rainfall) from subbasin to subbasin.

The physical characteristics of the Horton, Windsor, and Hopewell sediments indicate an arid to semiarid paleoclimate (McLeod, 1980). For example, the Memramcook, Weldon and Hillsborough formations and the Hopewell Group are primarily red bed sequences with widespread desiccation cracks, calcrete layers, and debris flows. Plant debris is rare or absent in these units suggesting a sparsely vegetated landscape. An arid to semiarid paleoclimate has been postulated (van de Poll, 1978) or inferred (McCutcheon, 1981a) during Windsor marine carbonate, sulphate and chloride deposition.

The paleoclimate during medial Albert time may have been relatively humid. Evidence of this includes: (1) widespread grey braided stream deposits in alluvial fans (fan-deltas), (2) thick lacustrine intervals, and (3) common to locally abundant plant material in both fluvial and marginal lacustrine beds. Transgressive and regressive cycles a few metres to tens of metres thick (St. Peter, 1992a, 1992b) in the Albert lacustrine section may represent alternating humid and dry climatic periods. For example, the Albert stratigraphy is analogous to the coarse (conglomerate and sandstone) and fine (silt and clay) repeating cycles less than $50 \mathrm{~m}$ thick in the Quaternary Alameda Creek fan of northern California. Koltermann and Gorelick (1992) have interpreted the coarse and fine Alameda Creek fan tongues as 
responses respectively to wet glacial and dry interglacial periods. The humid period implied for the medial Albert was short lived; the thick halite and glauberite deposits in the upper Albert indicate a return to more arid conditions. A decline in fern spores in the upper Albert Formation also suggests an upward drying trend (Varma, 1969).

In summary, the evidence suggests that except for medial Albert time the paleoclimate was arid to semiarid during the Horton and Windsor/Hopewell allocycles in the Moncton Subbasin. Assessments of the prevailing paleoclimate at various times during the Late Carboniferous and Early Permian in the Maritimes Basin have been given by McLeod and Ruitenberg (1978), van de Poll (1978), Legun and Rust (1982), and Browne (1990).

\section{TeCtonic SETTING}

As previously noted, the Maritimes Basin is underlain by an assemblage of five juxtaposed, deformed terranes or composite terranes, together comprising the northern Appalachian orogen (Figs. 1, 2,3). The terranes are internally cut by many east-, northeast-, and northwest-trending faults. Most of these faults are Devonian and older structures related to pre-Taconian, Taconian, and Acadian accretions (Webb, 1963, 1969; Belt, 1968; Eisbacher, 1969; Bradley, 1982; Keppie, 1992; Keppie and Dallmeyer, 1987; Nance, 1987; Mawer and White, 1987; Ferrill and Thomas, 1988; Williams and Hy, 1990; Stringer et al., 1991; Barr and White, 1991a). It is quite clear that the northern Appalachian basement crust prior to the inception of the Maritimes Basin was highly fragmented into a series of moreor-less rectilinear fault-bounded blocks.

The size, shape, and orientation of the basement fault blocks in southern New Brunswick are comparable to those elsewhere in the northern Appalachians and can be assessed from regional maps (Potter et al., 1979; Ruitenberg et al., 1979; Chandra, 1982; McCutcheon and Ruitenberg, 1987; Barr, 1988; Currie, 1989; Barr and White, 1989, 1991b; McLeod et al., 1994). The blocks range in width from less than $1 \mathrm{~km}$ to greater than 25 $\mathrm{km}$ and in length from less than $10 \mathrm{~km}$ to greater than $150 \mathrm{~km}$. The Caledonia and Brookville terranes of southern New Brunswick described by Barr and White (1991a) are examples of the larger blocks. The southern New Brunswick basement fault blocks are typically elongate, northeast-trending and rectangular to lozenge-shaped. Block length to width ratios are in the range of 5 to 1 to 10 to 1 . The overall fault-block geometry is comparable to the California Borderland anastomosing wrench system (Crowell, 1974a, 1974b, 1987; Reading, 1980). The fragmented fault blocks form both the upland source areas and the floor of the Maritimes Basin.

It is proposed that Late Palaeozoic displacements (reactivations) on major faults in the anastomosing network were responsible for the inception, subsidence and subsequent deformation of the Maritimes Basin and its component subbasins (cf. Belt, 1968; Webb, 1969; Bradley, 1982; Fralick and Schenk, 1981; Yeo and Ruixing (sic), 1987; Hyde, 1989; Hamblin, 1992; St. Peter, 1992a, 1992b). The following account of depositional, tectonic and kinematic evidence from the Moncton Subbasin agrees and supports the regional data. Reactivation of major ancestral faults is interpreted as the primary control on: (1) the inception of the Moncton Subbasin and, (2) the initiation, subsidence and termination of depositional cycles (allocycles) within the subbasin.

\section{Horton allocycle}

\section{Inception}

The oldest dated Horton Group (Memramcook Formation) strata are Late Devonian (Carr, 1968), implying that the Moncton Subbasin began to form in late Middle or Late Devonian time. There are presently insufficient data from (solely) the Moncton Subbasin to determine convincingly whether subbasin inception by fault reactivation was via dominantly dipslip (rifting) or strike-slip tectonics. Circumstantial evidence however infers an origin in a dextral oblique or strike-slip environment. It has been shown by radiometric dating of fabrics and Acadian accretion-related granites that the Meguma terrane docked with the Avalon terrane along the CobequidChedabucto Fault (Figs. 2, 3) throughout Devonian time (Keppie and Dallmeyer, 1987). During this time, movement on the Cobequid-Chedabucto Fault was dextral on mainland Nova Scotia (Eisbacher, 1969; Mawer and White, 1987; Keppie and Dallmeyer, 1987), and probably dextral reverse (thrust) where it curves southwestward in the Bay of Fundy (Figs. 2, 3) (Nance, 1986b, 1987). This implies a regional west-northwest- to northwest-oriented principal compressive stress (Brown and Helmstaedt, 1970; St. Jean et al., 1993, fig. 5). From this, it can be assumed that the Avalon terrane north and west of the Cobequid-Chedabucto Fault (i.e., at the present site of the Moncton Subbasin) would have been subject to dextral transcurrence during the Late Devonian inception of the Moncton Subbasin (cf. Leger and Williams, 1986). Specifically, the east- and northeast-trending basement faults would almost certainly be reactivated as dextral reverse(?) structures and the preexisting northwest-oriented cross-faults would act as tensional dip-slip fractures under the prevailing stress regime. Therefore, the complementary interactions of ancestral faults were responsible for the size, shape and northeast-orientation of the Moncton Subbasin.

The northwestern margin of the subbasin may have formed via oblique(?) up-on-the-north displacement on the pre-existing Belleisle, Kierstead Mountain and Kennebecasis faults (Brown and Helmstaedt, 1970, p. 764; Leger and Williams, 1986). The southeastern boundary of the subbasin was controlled by movement on the old Clover Hill Fault (Fig. 4), Gordon Falls Fault (Fig. 5), and Caledonia Fault (Figs. 6, 7) (St. Peter, 1992a, 1992b). The latter three faults closely follow the location of the Precambrian suture between the Caledonia and Brookville terranes (Barr and White, 1991a). The northeastern end of the Moncton Subbasin is in part defined by the north-northwesttrending Memramcook East Fault. This fault is largely covered by Cumberland Group strata but is seen on seismic reflection profiles to have a down-to-the-west normal dip-slip on basement rocks of about $700 \mathrm{~m}$ (St. Peter, 1992a, 1992b).

Albert Formation lithofacies boundaries in the southeastern part of the Moncton Subbasin trend north-northeast and are 
not parallel to the present basin-margin faults, thus implying that the subbasin may have opened obliquely to its present tectonic margins (St. Peter, 1992a, 1992b). Also, the Albert Formation in the eastern end of the subbasin contains north-trending sandstone dykes inferring that the local (within-basin) extension direction during Horton deposition was circa east-west (St. Peter, 1992a, 1-992b). This demonstrates that the subbasin probably did not open northwest-southeast parallel it its present margins via orthogonal rifting. In the Moncton Subbasin, as in many other ancient strike-slip basins (Mann et al., 1983, p. 549), the geometric and kinematic evidence of initial basinmargin faults is obliterated by multiple later displacements.

\section{Subsidence}

As previously noted, Horton Group fill in the Moncton Subbasin is up to $3.7 \mathrm{~km}$ thick. The group displays relatively rapid lateral lithofacies changes and an overall vertical coarsefine-coarse cyclicity. For example, the Memramcook and Weldon formations are largely coarse alluvial fan facies adjacent to the Caledonia Uplift, the New Brunswick Platform and intrabasinal basement blocks such as Jordan Mountain (Fig. 4). Both formations tend to be finer grained alluvial or fluvial sequences in the axial part of the subbasin. The medial Albert Formation on the other hand is dominantly fine-grained open lacustrine and playa lake facies with subordinate coarse fan-delta deposits along basin margins (St. Peter, 1992a, 1992b).

Clast compositions, paleocurrent analyses (McCutcheon, 1978; St. Peter, 1992a, 1992b), and the lateral architecture of lithofacies quite clearly demonstrate that basin-bounding faults controlled sedimentation during the Horton allocycle. The widespread coarse-grained lithofacies which characterize the lower and upper parts of the allocycle indicate relatively slow subsidence (Blair, 1987; Blair and Bilodeau, 1988). In contrast, the presence of thick fine-grained lacustrine strata in the Albert Formation along the subbasin southern margin indicates that subsidence resulting from faulting was most rapid during the medial part of the allocycle (Fig. 8) (Blair, 1987; Blair and Bilodeau, 1988).

\section{Termination}

There is fairly conclusive evidence that the Horton allocycle ended as a result of dextral transpression with ensuing inversion of the Moncton Subbasin. The significant details have been described by St. Peter (1992a, 1992b) and include: (1) development within the Horton sedimentary pile of braided wrench fault zones from movement of preexisting basement faults, (2) local formation of a strike-slip duplex along the southeastern margin of the Moncton Subbasin, (3) formation of en échelon folds associated with strike-slip faults, (4) formation of positive flower structures, (5) intrabasinal basement uplifts, (6) erosion, which has locally resulted in complete removal of the Horton section, and (7) creation of an angular unconformity at the base of the Visean Windsor Group.

A description and analysis of bedrock tectonic and seismic reflection evidence for inversion of the Horton section in the Moncton Subbasin is given in St. Peter (1992a, 1992). Selected evidence is given here, mainly from the southeastern part of the subbasin, to demonstrate the style of deformation.

Most faults in the Moncton Subbasin are long linear features with only local curvature. This suggests that they are steeply dipping structures (Fig. 4), and is confirmed in rare good exposures where faults are exposed. Examples include: (1) the Taylor Village, Round Hill and Boudreau faults in the section on the east bank of the Petitcodiac River at Boudreau Village (Fig. 7), (2) the Belliveau and Saint-Joseph faults in the section on the east side of the Petitcodiac River at Belliveau Village (Fig. 7), and (3) the Gaytons Fault in a basement aggregate quarry 2 $\mathrm{km}$ north of Gaytons (Fig. 4). Seismic reflection profiles provide supporting evidence that the faults are mainly steeply dipping (Figs. 9a,b,c, 10a,b).

The northeast- to east-northeast-trending faults show convincing evidence of dextral lateral movement and/or reverse dip-slip movement. Dextral offsets are shown by displaced contacts and by numerous right-handed en échelon megascopic folds [Figs. 5, 6, 7; see Wilcox et al. (1973) for right-handed and left-handed fold definitions]. Further evidence of dextral offset is shown: for example, by mesoscopic S-shaped folds with northeast- to east-striking and shallowly to steeply plunging hinge lines along the Belliveau and Saint-Joseph faults, and by displacements on sandstone dykes cut by the Boudreau Fault.

Reverse displacements on northeast-trending faults are shown by locally overturned bedding in Horton strata and by juxtaposition of older rocks over younger ones. For example, the Albert Formation on Frederick Brook between the Edgetts Landing and Dorchester faults (Fig. 7) shows a gradual increase in dip over a distance of $500 \mathrm{~m}$, from $55^{\circ} \mathrm{S}$ just south of the Edgetts Landing Fault to $80^{\circ} \mathrm{N}$ (overturned towards the south) just north of the Dorchester Fault. The change in bedding attitude associated with the reverse faulting suggests the presence of a drag fold of the Albert beds over the Windsor and Cumberland conglomerates to the south. From this relationship it is seen that the latest reverse movement on the Dorchester Fault post-dates the Cumberland Group. However, the steep dip of the Albert beds in contrast to the subhorizontal disposition of the Windsor and Cumberland conglomerates implies that most of the displacement pre-dated the basal Windsor unconformity.

Reverse offset on the Prosser Mountain and Belliveau faults is indicated at Prosser Brook by the juxtaposition of basement rocks on the north against Windsor strata on the south (Fig. 6). On seismic line L9l (Figs. 6, 9a,b,c) opposing senses of reverse displacement on the Belliveau and Hillsborough faults result in the formation of an intervening syncline, which gradually widens with depth. It is apparent on line L91 that most of the reverse displacement on the Hillsborough and Belliveau faults pre-dated deposition of the Hillsborough Formation (Windsor Group).

Reverse south-over-north movement on the Pollett River Fault is apparent from north-younging overturned Albert beds on the north side of the fault at Webster Brook, Pollett River, and Pleasant Vale (Fig. 5) (St. Peter, 1992a, 1992b). Upthrow of the south wall of this fault is also implied by older Memramcook rocks lying on the south hanging wall side.

In plan view there is a major northwest-facing concave bend in the Gordon Falls and Pollett River faults in the Elgin area 
(Fig. 5). Since these faults show dextral offset, the bend is a restraining bend (Crowell, 1974a). On the north side of the Pollett River Fault and on the northeast arm of the bend there are three lenticular fault blocks bounded by the Pollett River, Pleasant Vale, Mapleton, Elgin, and Parkindale faults (Fig. 5). The lenticular shape of these blocks and their relationship to the bend resembles what Woodcock and Fischer (1986) describe as a contractional strike-slip duplex. This interpretation of fault geometry and kinematics is supported by the repetition of lithologic facies in the Albert Formation within the blocks (St. Peter, 1992a, 1992b), and by the presence along strike to the northeast of positive flower structures. The presence of positive flower structures [see Sylvester and Smith (1976), and Harding (1985) for definition and examples] is interpreted on seismic profiles L91 (Fig. 9a,b,c). The surface shape of the duplex and its vertical geometry interpreted as a positive flower structure is strikingly similar to that postulated by Woodcock and Fischer (1986, fig. 12b).

Analysis of available seismic reflection lines in the southeastern Moncton Subbasin shows that dextral reverse displacements on the northeast-trending faults have resulted in formation of classic positive flower structures (Sylvester and Smith, 1976; Harding, 1985). An example is shown by the Prosser Mountain, Belliveau, and Gowland Mountain faults (Fig. 5). An axial push-up associated with the positive flower in this zone is defined by the basement ridge striking northeast from Little River to Prosser Brook (Figs. 5, 6).

The amount of movement on individual northeast-trending faults in the southeastern Moncton Subbasin is very difficult to ascertain. The virtual certainty that displacements on many of these faults was oblique rather than pure strike-slip, further complicates the problem. For instance, if the duplex model interpreted for the fault geometry northeast of Elgin is correct, then the repetition of Albert conglomerate facies (St. Peter, 1992a, 1992b) suggests dextral lateral offset on the Pollett River Fault of perhaps 10 to $20 \mathrm{~km}$. If, on the other hand, the facies repetition is largely controlled by reverse dip-slip, then the lateral displacement would be much reduced.

It seems quite likely that significant dip-slip has occurred on many of the northeast-trending faults. Upthrow of basement rocks on the south of the Gordon Falls Fault is greater than 700 m (Fig. 10a,b). The dip-slip offset of basement rocks on the steeply dipping Boudreau Fault is about $1.5 \mathrm{~km}$, and on the Dorchester Fault about 800 m (St. Peter, 1992a, 1992b). From the above estimates it appears that lateral movements on the northeast-trending faults are in the range of a few hundred metres to a few tens of kilometres. Dip-slip displacements may be $2 \mathrm{~km}$ or greater on some basin-margin faults.

Displacements on the northeast-trending faults are largely pre-Windsor in age. This is best seen by examination of Figures 4, 5, 6 and 7 and interpreted seismic profiles (Figs. 9c, 10b) from which it is seen that Horton rocks are folded, and that Horton Group fault offsets are much greater than in the shallowly dipping overlying Windsor/Hopewell depositional sequence.

From the above discussion the author concludes that the Horton allocycle terminated as the result of dextral transpressive faulting that led to braided wrench fault zones with associated en échelon right-handed folds, duplex structures and positive flower structures. Erosion resulted from this structural inversion of the Horton section and over the most rapidly rising blocks the complete Horton section was removed. This is evident, for example, where basement is exposed at Jordan Mountain and Gaytons (Fig. 4) and over the basement ridge between the Prosser Mountain and Belliveau faults (Fig. 6). The combined effect of transpression and erosion resulted in folding and segmentation of the Horton section. The end of the Horton allocycle is indicated by Hillsborough conglomerates, which unconformably overlie both the basement and the incompletely eroded structurally preserved remnants of the Horton sections.

\section{Windsor/Hopewell allocycle}

\section{Inception}

The Windsor/Hopewell allocycle began in the early Visean as first recorded by deposition of the coarse clastic Hillsborough Formation (Table 1). The distribution of the Hillsborough Formation and the basin-margin lithofacies of the overlying ma. rine Gays River and Parleeville formations (McCutcheon, 1981b) indicate that the site of deposition during the Windsor/Hopewell cycle was largely coincident with that of the former Horton allocycle (Fig. 4).

The initial subsidence of the Windsor/Hopewell depocentre does not appear to have resulted from movement or, basin-bounding faults as was the case during the earlier Horton cycle. Evidence for this includes: (1) the very gradual changes in thickness of the regionally distributed Hillsborough Formation, (2) the absence of any apparent changes in lithofacies in the Hillsborough that would, for example, suggest proximal/ distal relationships (the formation is nearly exclusively coarse-grained), and (3) the widespread preservation of the basal Hillsborough unconformity, which typically onlaps basement and Horton rocks without showing evidence of syndepositional faulting. Therefore, during the early Windsor part of the cycle the Moncton Subbasin appears to have developed by down-flexing or sagging.

\section{Subsidence}

The regional vertical cyclicity of coarse-fine-coarse lithofacies shown by the Windsor and Hopewell groups is believed to reflect a gradually changing tectonic cyclicity within the Moncton Subbasin. The coarse-grained Hillsborough Formation at the base of the Windsor Group is widely distributed and implies relatively slow subsidence during the early part of the allocycle (Blair, 1987; Blair and Bilodeau, 1988). The regional variations in thickness of the Hillsborough Formation indicate unequal rates of subsidence; for example, the Hillsborough pinches out over the crest of the Westmorland Uplift. The most rapid subsidence during this time seems to have been in the area from Lower Millstream to Havelock where the Hillsborough Formation is at least $\mathbf{4 0 0} \mathrm{m}$ thick (Fig. 4).

The local sagging that began in Hillsborough time spread to the entire Maritimes Basin by the Middle Visean as indicated by inundation of the Windsor sea (Schenk, 1969; 
$\mathrm{S}$

LINE 9|

N

0

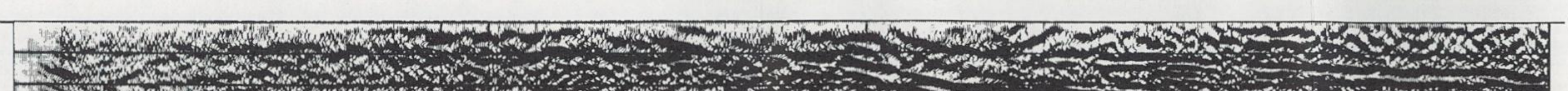

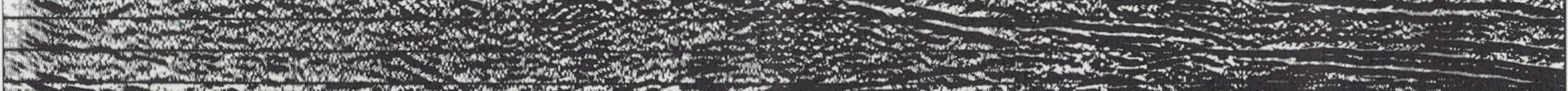

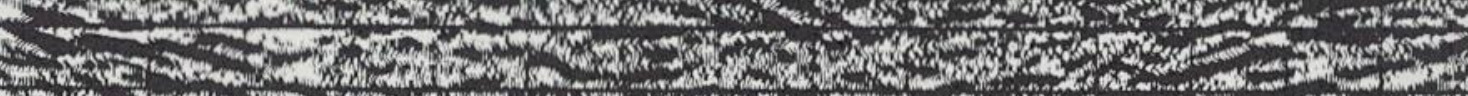

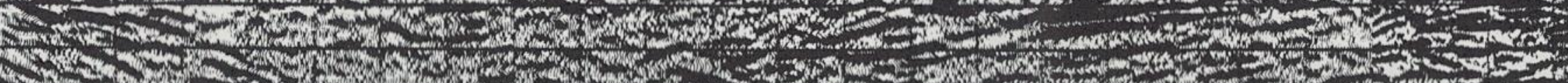

○

N.t.

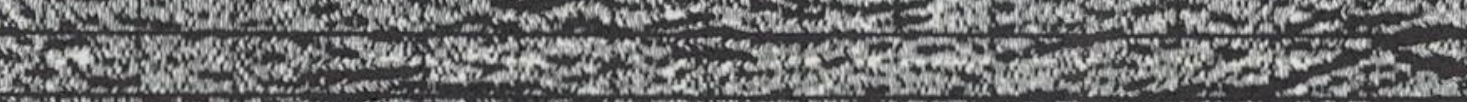

$\stackrel{\vdash}{\lessgtr}$

$\stackrel{1}{\risingdotseq} 1.0-\frac{1}{2}$

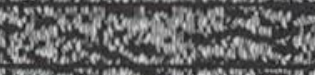

T.

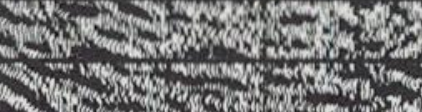

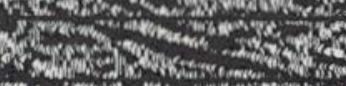

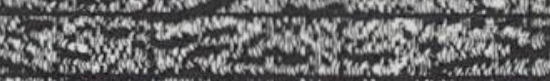

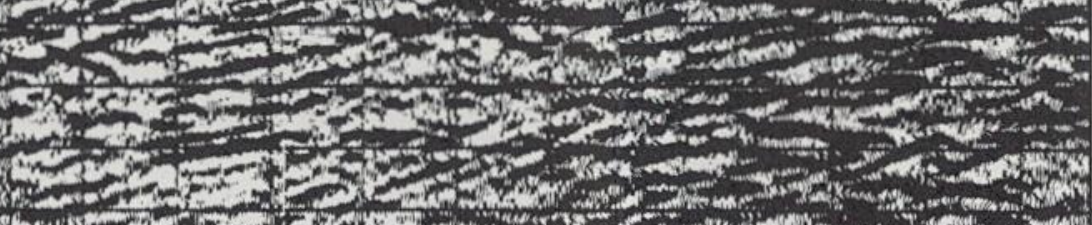

ํํㅇ

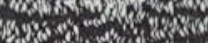

Crow

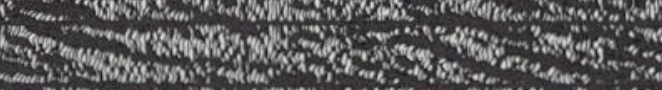

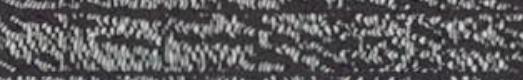

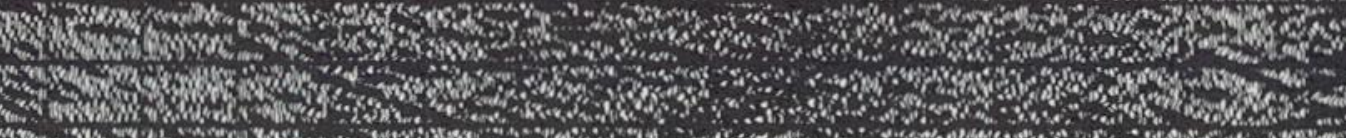

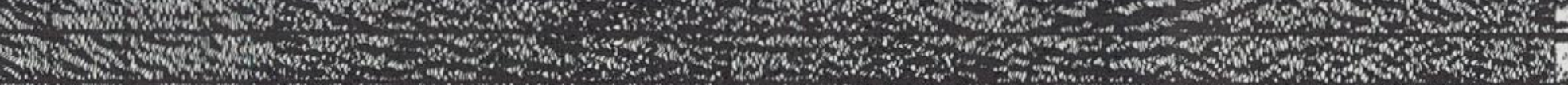

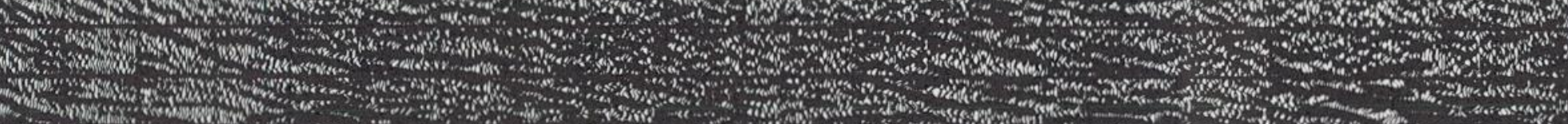

2.0 D 
LINE 91

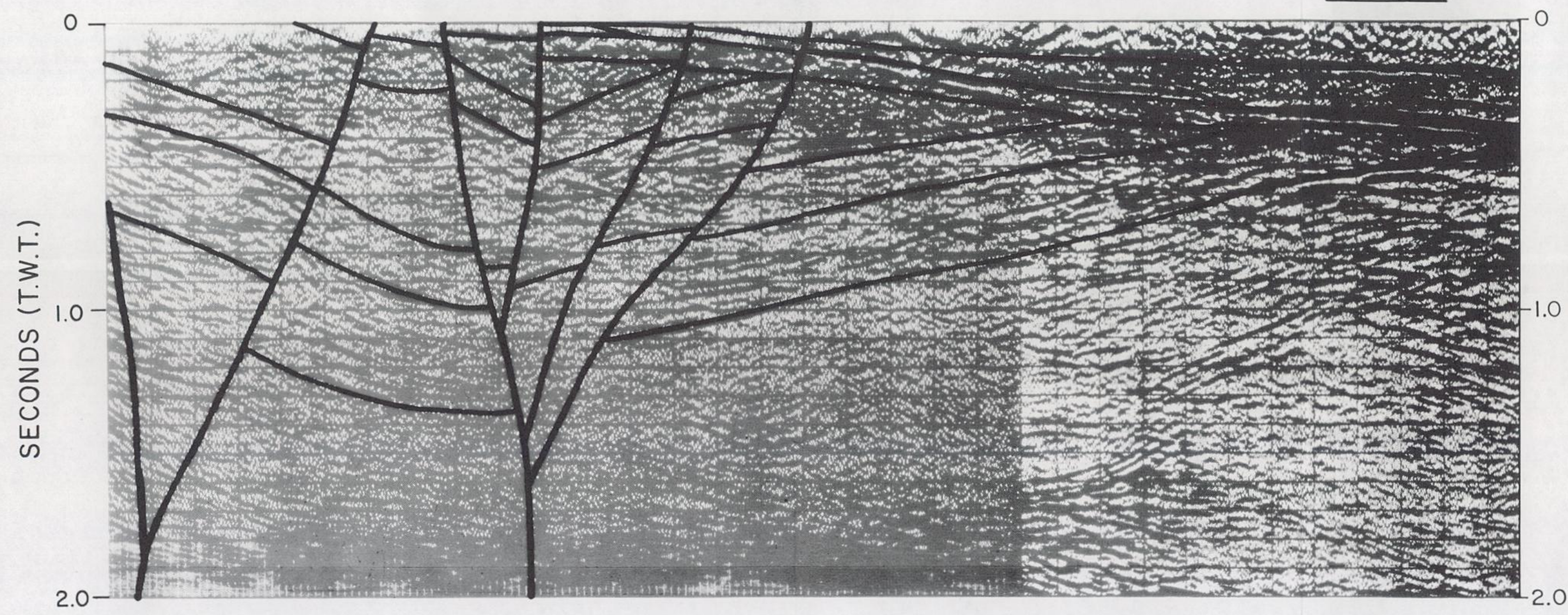

Fig. 9b. Chevron Canada Resources Limited seismic line 91 (migrated, 2000\%). Interpreted boundaries of seismic sequences, seismic facies, and faults. 


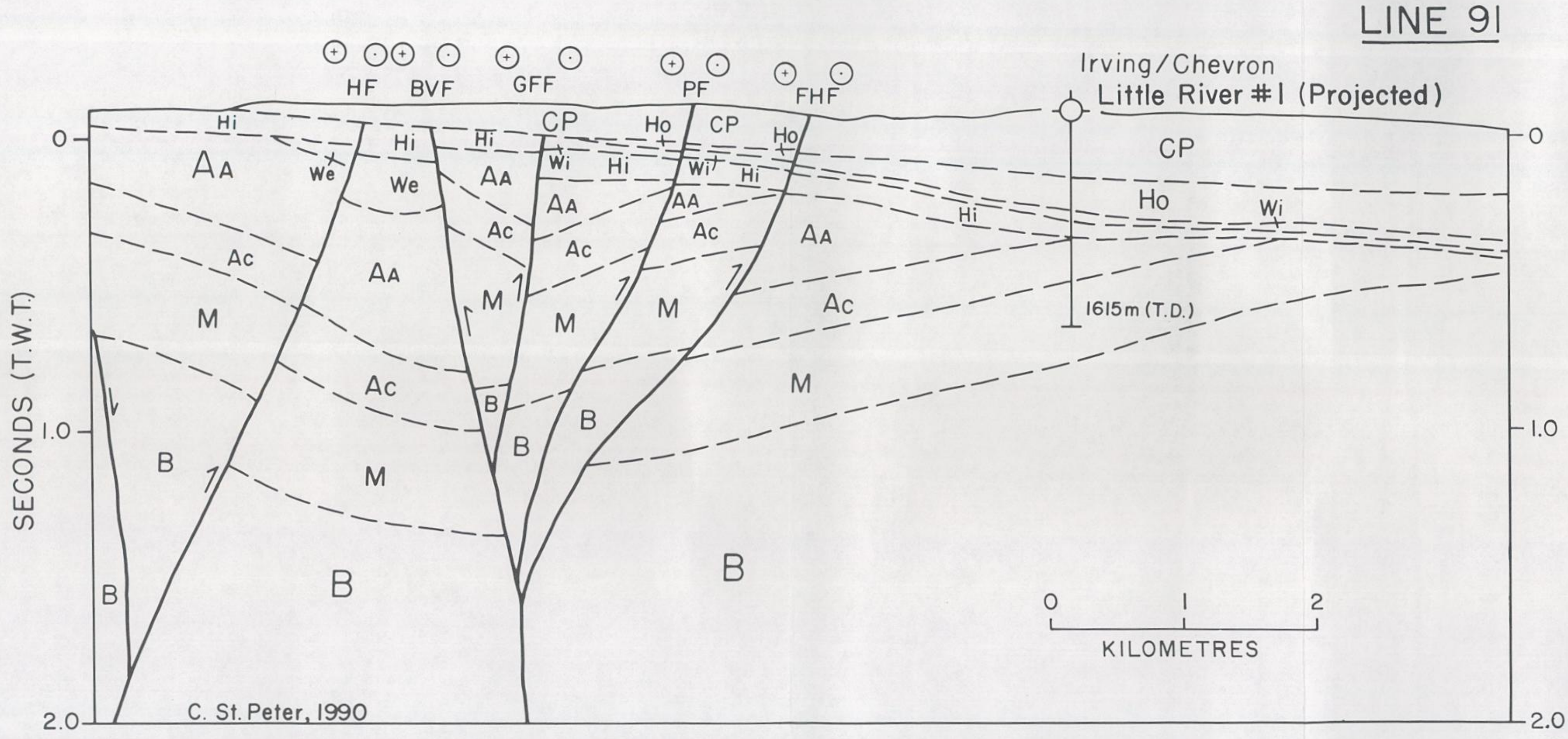

Fig. 9c. Chevron Canada Resources Limited seismic line 91 (migrated, 2000\%). Geological interpretation; symbols: B = Basement complex; M $=$ Memramcook Formation; $\mathrm{AA}=$ Albert Formation (interbedded clastic facies undivided); $\mathrm{Ac}=$ Albert Formation (fine-grained facies); We Hillsborough Fault, BVF $=$ Belliveau Fault, GFF $=$ Gordon Falls Fault, PF $=$ Parkindale Fault; FHF $=$ Forest Hill Fault; $\oplus$ and $\odot=$ away an toward sense of movement on fault. 


\section{LINE 5Y}

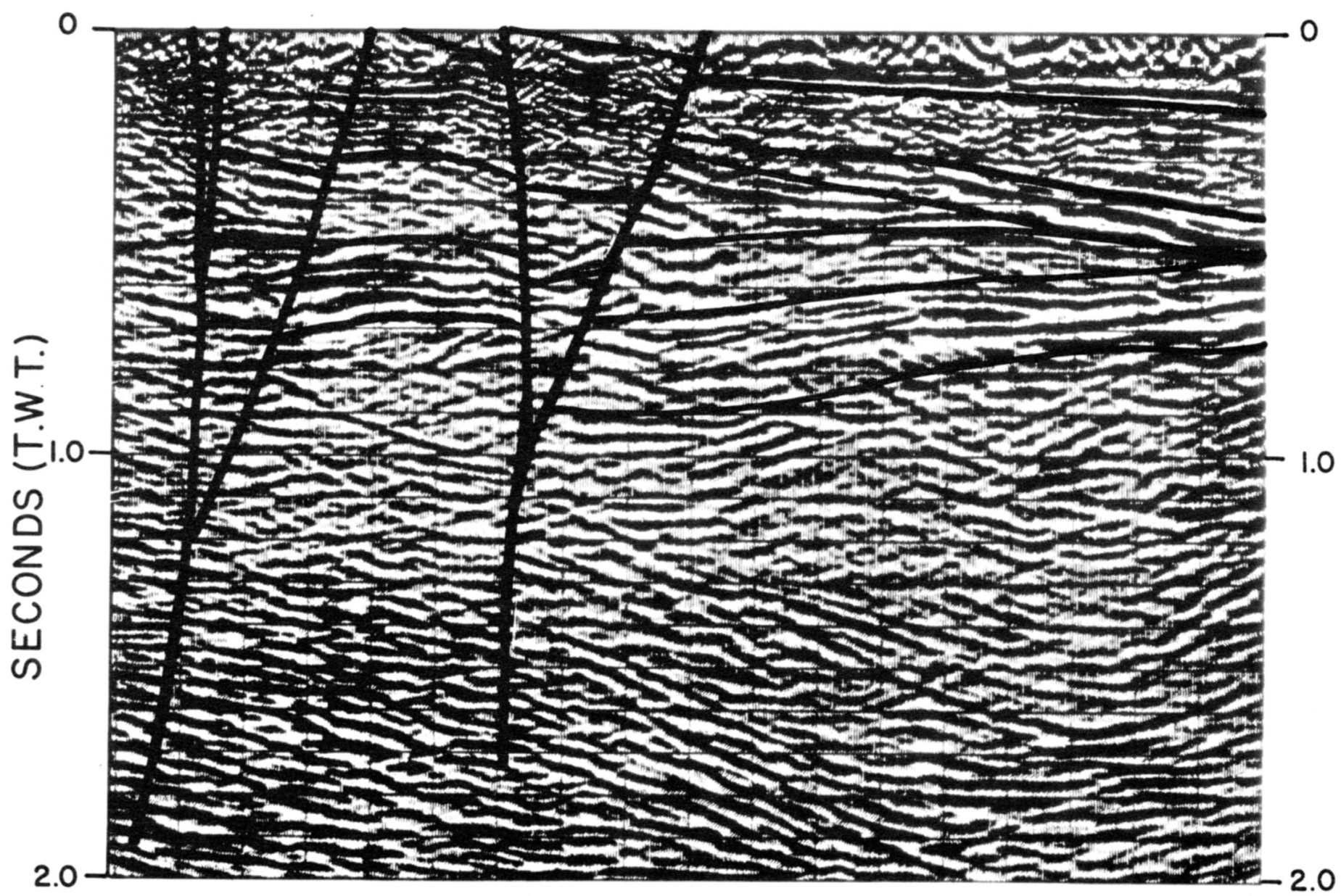

Fig. 10a. Chevron Canada Resources Limited seismic line 5Y (migrated, 3000\%). Interpreted boundaries of seismic sequences, seismic facies, and faults. (See Figure 5 for line location.)

McCutcheon, 1981a; Knight, 1983). The lithofacies distributions of the basal littoral Gays River and Parleeville formations and the sublittoral Macumber Formation of the Windsor Group (McCutcheon, 1981a, fig. 4a) suggest that gradual sagging dominated the early marine part of the cycle. The Windsor carbonates are succeeded by several hundreds of metres of evaporites (sulphates and chlorides) in the deepest parts of the Moncton, Sackville, Cumberland, and Magdalen subbasins (Fig. 3; Howie and Barss, 1974; Boehner, 1985; Howie, 1988). Applying the model set forth by Blair (1987) and Blair and Bilodeau (1988), the fine-grained thick chemical strata imply a significant increase in the rate of subsidence in the medial Windsor section in the Moncton and other subbasins of the Maritimes Basin (Fig. 8) (Geldsetzer, 1978). It is taken from this that by medial Windsor time, and continuing into Hopewell time, faulting within individual subbasins was reestablished as the dominant control on the accelerating subsidence.

Schenk (1969), Howie and Barss (1974), McCutcheon (1981a), and Knight (1983) have demonstrated the presence of coarse alluvial conglomerates along the margin of some subbasins in the upper part of the Windsor section. In a similar way, Hopewell Group deposits in the western part of the Moncton Subbasin near the Caledonia Uplift comprise mainly coarse polymictic fanglomerates (Gussow, 1953). The proximal marginal conglomerates there give way to the north and west to distal Hopewell red mudstones and fine-grained sandstones in the axial part of the subbasin (Anderle et al., 1979; McCutcheon, 1981a; Waugh and Urquhart, 1985). Seismic evidence of facies changes in the Hopewell Group has been documented by St. Peter (1992a, 1992b). The proximal (coarse) and distal (fine) lithofacies geometry of the Hopewell beds indicate that basinmargin faults controlled sedimentation and subsidence during the medial to upper part of the Windsor/Hopewell allocycle. The stratigraphic transformation from marine evaporites to coarse continental clastics implies a gradual decrease in subsidence throughout Hopewell time (Fig. 8).

Documentation of the style of faulting responsible for the accelerated subsidence phase of the Windsor/Hopewell allocycle has not been described in the literature (Geldsetzer, 1978; Kingston and Dickie, 1979; McCutcheon, 1981a; Ruitenberg and McCutcheon, 1982; Boehner, 1985; Boehner et al., 1986; Howie, 1986, 1988). The postulated existence of synsedimentary 


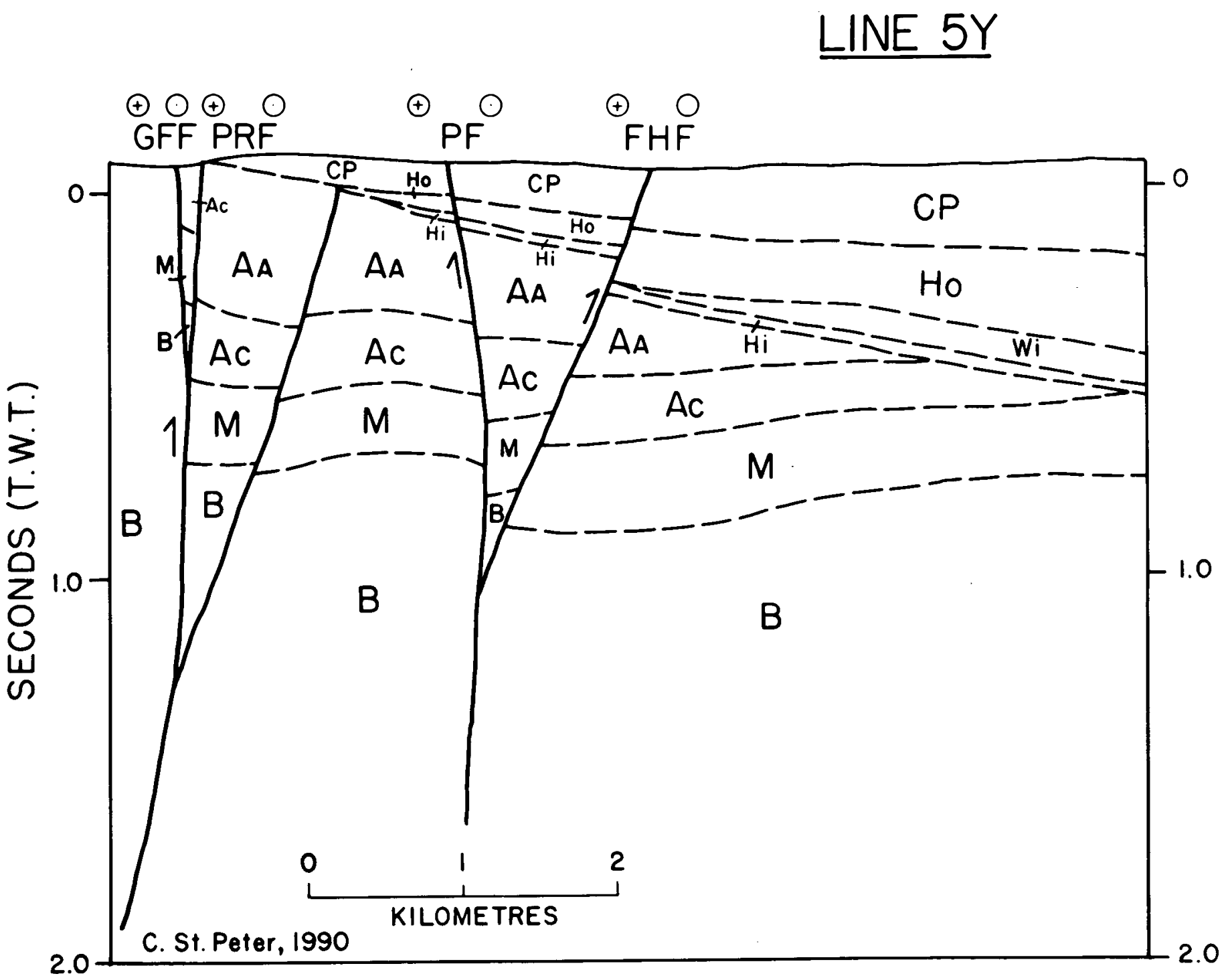

Fig. 10b. Chevron Canada Resources Limited seismic line 5Y (migrated, 3000\%). Geological interpretation; symbols: B = Basement complex; M $=$ Memramcook Formation; $\mathrm{AA}_{\mathrm{A}}=$ Albert Formation (interbedded clastic facies undivided); $\mathrm{Ac}=$ Albert Formation (fine-grained facies); Hi $=$ Hillsborough Formation; Wi $=$ Windsor Group; Ho $=$ Hopewell Group; $\mathrm{CP}=$ Cumberland and Pictou groups; GFF $=$ Gordon Falls Fault; PRF = Pollett River Fault; PF $=$ Parkindale Fault; FHF $=$ Forest Hill Fault; $\Theta$ and $\odot=$ away and toward sense of transcurrent movement on fault.

fault-bound(?) deep troughs controlling deposition of the Cassidy Lake Formation (Table 1) is alluded to by Roulston and Waugh (1981). The presence of synsedimentary Windsor-age faults is evident on northwest-southeast oriented industry seismic reflection profiles across the Case Syncline south of Lower Millstream (Fig. 4) (Silverstone, 1982). There, several northeaststriking down-to-the-basin extensional normal faults define the location of evaporite-filled troughs containing up to $500 \mathrm{~m}$ of salt. Displacements on the normal faults is confined to the Windsor and older beds; the faults do not cut the overlying Hopewell strata (Silverstone, 1982). An exception is the northdipping Kennebecasis Fault (Fig. 4). It shows later reverse reactivation of the normal fault system which delimits the southeast flank of the Case Syncline. In summary, it seems that subsidence during the medial part of the Windsor/Hopewell allocycle was locally more rapid as a result of extensional normal faulting.

\section{Termination}

The Windsor/Hopewell allocycle ended during the Namurian (Table 1). The most obvious evidence of the cessation of sedimentation and the initiation of basin inversion and erosion is the post-Hopewell/pre-Cumberland angular unconformity or disconformity (Table 1, Fig. 4). Hopewell and much of the upper Windsor section is missing below the unconformity in the southeastern Moncton Subbasin.

The tectonic event responsible for the termination of the Windsor/Hopewell allocycle is the second major compressional (transpressional ?) event to affect the Maritimes Basin ( $\mathrm{V}_{2}$ on Fig. 8). Evidence of this tectonism is shown by reverse reactivation of faults, particularly those faults that were previously responsible for deformation of the Horton strata. A number of these faults in the southeastern Moncton Subbasin do not offset the unconformably overlying Cumberland Group strata. Ex- 
amples include the Prosser Mountain, Belliveau, and Hillsborough faults (Fig. 6). The age of the reverse displacement on the Prosser Mountain Fault is quite clear from map relationships. The Hillsborough Formation (Windsor Group) immediately south of the fault dips northwesterly and apparently beneath the Prosser Mountain basement block (Fig. 6). The northwest dip and up-on-the-north offset on the fault is seen on seismic line 91 (Fig. 9a,b,c). The distribution of the Boss Point Formation east of the Prosser Mountain basement block suggests little if any displacement of Cumberland Group rocks by the Prosser Mountain Fault (Fig. 6; Gussow, 1953).

It is not clear whether there was any significant transcurrent movement associated with those faults with demonstrated $V_{2}$ reverse displacements. For example, the Prosser Mountain Fault zone has yet to be examined for kinematic indicators. The Hillsborough and Belliveau faults are interpreted to dextrally offset the Windsor/Horton contact on the west side of the Petitcodiac River, but outcrop control is insufficient to unequivocally constrain the map pattern (Fig. 7). The Belliveau Fault is exposed on the east bank of the Petitcodiac River where it cuts the Weldon Formation. There, in a wide deformed zone, all strain indicators (slickensides, vein and bed offsets, mesoscopic fold asymmetry, and riedel shears) show a dextral sense of displacement. The timing of this deformation is not completely fixed. It may be in part or entirely related to the earlier $V_{1}$ tectonism. It is tentatively concluded however that dextral (oblique) movement occurred on the $V_{2}$ structures, based on the fact that dextral (oblique) displacements have been quite convincingly demonstrated on both earlier $V_{1}$ and later $V_{3}$ structures. There is no apparent reason to interpret a significant change in the orientation of the regional stress regime during $\mathrm{V}_{2}$ time.

There was no basin-wide folding associated with tectonism at the end of the Windsor/Hopewell cycle. Seismic reflection profiles (Figs. 9a,b,c, 10a,b) suggest only a gentle tilting of the Windsor and Hopewell beds prior to Cumberland deposition. The only places where Windsor and Hopewell strata show moderate or steep dips is in proximity to faults and/or in sections affected by salt tectonics (Waugh and Urquhart, 1985; Howie, 1988). The north- to northwest-trending open folds in the Windsor beds on the west side of the Petitcodiac River in the southeastern Moncton Subbasin are not related to the $\mathrm{V}_{2}$ deformation (Fig. 7). Open folds with a similar orientation in the Enragé and Boss Point formations on either side of the Petitcodiac River give clear evidence that the folds in the Windsor rocks result from a later post-Cumberland $\left(\mathrm{V}_{3}\right)$ deformation event (Fig. 8).

\section{Deformation postdating Windsor/Hopewell allocycle}

As described above under Stratigraphy in Moncton SuBBASIN, the Windsor/Hopewell allocycle was succeeded by two mainly fluviatile sequences - the Cumberland and Pictou groups - which are widely distributed across the Maritimes Basin (Fig. 4) (Howie and Barss, 1975; Ryan et al., 1991). The crustal downwarping that created the depocentre into which the Cumberland and Pictou beds were deposited was considered by
Bradley (1982) to have been a single event resulting from thermal relaxation of the lithosphere following an earlier phase of lithosphere stretching during basin inception. The Westphalian $\mathrm{C}$ disconformity or unconformity $\left(\mathrm{V}_{3}\right.$, Fig. 8) between the Cumberland and Pictou groups (Ryan et al., 1991) demonstrates that the evolution of the Maritimes Basin following the Windsor/ Hopewell allocycle was not a single uninternupted thermal subsidence/depositional event.

The Cumberland Group strata in the Moncton Subbasin are folded and faulted (Figs. 4, 7). For example, the Boss Point Formation is folded in the Marchbank Syncline and overthrust by basement (?) and Horton Group rocks along the Clover Hill Fault (Fig. 4). The Enragé and Boss Point formations are also cut by several faults showing dextral displacements in the southeastern Moncton Subbasin (Fig. 7). The en échelon right-handed open folds associated with these faults suggest the faults and folds are genetically related. However, it is not possible to determine (because the Pictou Group is absent) if the deformation in the Cumberland Group in the southeastern Moncton Subbasin is associated with the $V_{3}$ tectonic event or if it postdates Pictou deposition. Regionally, it is seen that there is a period of deformation which postdates the Cumberland Group and predates the Pictou Group. For example, just south of Amherst, Nova Scotia, folded and faulted rocks of the Cumberland Group in the salt-cored Minudie Anticline are clearly unconformably overlain by undeformed gently tilted Pictou beds (Ryan $e t$ al., 1990b). For this reason it is speculated that the deformation affecting the Cumberland Group along the south side of the Moncton Subbasin is associated with the $V_{3}$ event (Fig. 8).

Following the $V_{3}$ deformation, regional sagging occurred which affected the entire Maritimes Basin. This is evident by deposition of the widely distributed late Westphalian $C$ to Early Permian Pictou Group (Fig. 1) (Howie and Barss, 1975; Bradley, 1982). Downflexing of the crust was succeeded in postEarly Permian time by a final phase of deformation related to Variscan orogenesis. The best example of this late tectonism is along the Berry Mills/Smith Creek fault system north and west of Moncton (Fig. 4). The Berry Mills/Smith Creek fault zone is a braided dextral transpressive network with associated positive flower structures, and is analogous to the fault zones in the southeastern subbasin (St. Peter and Fyffe, 1990; St. Peter, 1992a, 1992b). However, significant movement in this zone is later than in the southeast as shown by greater than $2 \mathrm{~km}$ of reverse dip-slip offset on the basal Windsor seismic reflector across the Berry Mills Fault (St. Peter, 1992a, 1992b). Also, the Pictou Group is seen in outcrop along an unnamed tributary of McQuade Brook north of Moncton to be very steeply dipping along the Lutes Mountain Fault (St. Peter, unpublished data).

The Berry Mills Fault links up with the Kennebecasis Fault zone southwest of Sussex (Fig. 4). The same fault system continues along strike to the southwest for $100 \mathrm{~km}$ where it is seen to shear the Lepreau Formation. Folds and cleavage in the Lepreau red beds have been interpreted as compressional structures related to wrench faulting (Stringer and Lajtai, 1979). Palynological analysis of the Lepreau Formation indicates a Lower Carboniferous (late Visean) age (Stringer and Burke, 1985, p. 4). 


\section{SUMMARY AND CONCLUSIONS}

The depositional and tectonic evolution of the Maritimes Basin was controlled by: (1) the lithologic composition and tectonic architecture of basement terranes underlying the Basin and (2) tectonic cyclicity during basin fill.

Basement architecture beneath the Maritimes Basin is defined by five deformed terranes (Figs. 1, 2, 3). The terranes were largely accreted during Taconian and Acadian orogenesis (Bird and Dewey, 1970; Williams and Hatcher, 1982). The terranes are cut by many interterrane and intraterrane faults with predominantly northeast, east, and northwest orientations (Webb, 1969; Belt, 1968; Eisbacher, 1969; Bradley, 1982; Keppie, 1982, 1992; Ferrill and Thomas, 1988; Williams and Hy, 1990; Stringer et al., 1991). Thus, it is apparent that the crust beneath the Maritimes Basin was highly fragmented into a series of northeast- and east-trending elongate fault-bounded blocks. The fault blocks have widths of 1 to $25 \mathrm{~km}$, lengths of less than 10 to greater than $150 \mathrm{~km}$, and length to width ratios of 5 to 1 to 10 to 1 . It is noted that the component subbasins of the Maritimes Basin have similar areal shapes and length to width ratios as the basement fault blocks. It is implied from this that relative movements of adjacent fault blocks were responsible for the inception of subbasins and intervening uplifts (source areas).

Depositional cyclicity in the sedimentary fill in the Moncton Subbasin (and by analogy within other Maritimes Basin subbasins) is interpreted to have resulted from tectonic cyclicity. Evidence of depositional cyclicity includes angular unconformities or disconformities between: (1) the Horton and Windsor groups (cf. Smith and Collins, 1984), (2) the Hopewell and Cumberland groups, and (3) the Cumberland and Pictou groups (Table 1). The Horton and Windsor/Hopewell allocycles in the Moncton Subbasin display a coarse-fine-coarse stratigraphic symmetry (Table 1). The fine-grained medial part of each cycle is interpreted to result from accelerated subsidence (Fig. 8) (Blair, 1987; Blair and Bilodeau, 1988), thus accounting for the impoundment of closed lakes in the Horton cycle and rapid marine invasion in the Windsor/Hopewell cycle.

The stratigraphic symmetry of the Horton and Windsor/ Hopewell allocycles can be attributed to three stages: (1) basin inception, (2) basin subsidence and infilling, and (3) depositional termination by basin inversion. It is not yet clear how the Moncton Subbasin opened during the Horton allocycle. Was it by: (a) orthogonal or (b) oblique displacements on basin-bounding faults? A dextral oblique opening is suggested from indirect evidence, including (1) the interpreted effect of Meguma/ Avalon accretion on pre-existing basement faults, (2) Horton Group lithofacies spatial relationships, and (3) Horton sandstone dyke orientations. Seismic reflection profiles indicate that the rapid subsidence during the medial Windsor/Hopewell cycle was largely controlled by normal faults related to northwestsoutheast extension.

Both the Horton and Windsor/Hopewell depositional cycles terminated as a result of basin inversion via dextral transpression. This is particularly clear for the end of the Horton allocycle where both geologic and seismic reflection evidence show braided wrench faults, associated en échelon folds, du- plex structures, and positive flower structures in the Horton section (Figs. 4, 5, 6, 7, 9a,b,c, 10a,b).

A Westphalian $C$ unconformity between the Cumberland and Pictou groups demonstrates that the late history of the Maritimes Basin was not a single thermal subsidence and depositional event (cf. Bradley, 1982). Structures associated with this deformation include reverse faults (i.e., Clover Hill Fault) and right-handed open folds related to dextral faults in the southeastern Moncton Subbasin (Fig. 7).

In conclusion it is apparent that southern New Brunswick in the Late Palaeozoic was the site of repeated tectonic cycles which reactivated major basement faults. Most of these faults show dextral displacements and are interpreted as the primary control on: (1) inception of the Moncton Subbasin, and (2) initiation, subsidence and termination of allocycles within the subbasin. By analogy, it is suggested that reactivation of preexisting major basement faults was responsible for the formation and subsequent deformation of the sedimentary fill in other component subbasins of the Maritimes Basin. It is further speculated that prolonged dextral docking of the Meguma terrane with the Avalon terrane (or in a more global plate tectonic sense, Gondwana with Laurentia) during the Devonian and Carboniferous (Eisbacher, 1969; Mawer and White, 1987; Keppie and Dallmeyer, 1987) was directly or indirectly responsible for the reactivation of pre-existing basement faults and thus the cyclical formation and deformation of the Maritimes Basin allocycles (cf. Ryan et al., 1988)

\section{ACKNOWLEDGements}

Some of the data for this paper were taken from the author's University of New Brunswick M.Sc. geology thesis. In this regard I would like to thank Drs. J.P.A. Noble and K.B.S. Burke for sharing their ideas during thesis preparation. The original draft of the paper was reviewed by F.W. Chandler and A.C. Grant. Their commentary was much appreciated and greatly improved the text and figure presentations. I am grateful to Gerry Johnson and Terry Leonard of New Brunswick Department of Natural Resources and Energy for drafting the figures and table and particularly for their patience during figure revisions.

Anderle, J.P., Crosby, K.S., and Waugh, D.C.E. 1979. Potash at Salt Springs, New Brunswick. Economic Geology, 74, pp. 389-396.

Ball, F.D., Sullivan, R.M., and Peach, A.R. 1981. Carboniferous drilling project. New Brunswick Department of Natural Resources, Mineral Resources Branch, Report of Investigation No. 18, 109 p.

BARR, S.M. 1988. Geology of eastern Caledonian Highlands, New Brunswick. Geological Survey of Canada, Open File Report 1774, map plate 88-14.

BARR, S.M. and RAESIDE, R.P. 1989. Tectono-stratigraphic terranes in Cape Breton Island, Nova Scotia: implications for the configuration of the northern Appalachian orogen. Geology, 17, pp. 822825.

BARR, S.M. and WhITE, C.E. 1989. Revised geological map of the central Caledonian Highlands, southern New Brunswick (parts of 21/H5, 6, 10, 11, 12, 14, 15). Geological Survey of Canada, Open File Report 2071, map plate 89-96. 
1991a. Revised stratigraphy of the Avalon terrane of southern New Brunswick. In Geology of the coastal lithotectonic block and neighbouring terranes, eastern Maine and southern New Brunswick. Edited by A. Ludman. New England Intercollegiate Geological Conference 83rd Annual Meeting, Princeton, Maine. Wm. C. Brown Publishers, Debuque, Iowa, pp. 1-12

1991b. Late Precambrian-Early Cambrian geology, Saint John - St. Martins area, southern New Brunswick (parts of $21 \mathrm{H} / 5$, $21 \mathrm{H} / 12$, and $21 \mathrm{G} / 8$ ). Geological Survey of Canada, Open File Report 2353, map plate 91-29.

Barr, S.M., Bevier, M.L., White, C.E., and Doig, R. 1993. Magmatic history of the Caledonia (Avalon) terrane of southern New Brunswick based on U-Pb (zircon) geochronology. In Current Research. Compiled and edited by S.A. Abbott. New Brunswick Department of Natural Resources and Energy, Mineral Resources, Information Circular 93-1, pp. 10-17.

Barss, M.S. and Hacquebard, P.A. 1967. Age and the stratigraphy of the Pictou Group in the Maritime Provinces as revealed by fossil spores. In Collected Papers on Geology of the Atlantic Region Hugh Lilly Memorial Volume. Edited by E.R.W. Neale and H. Williams. Geological Association of Canada, Special Paper 4, pp. 267-282.

BELL, W.A. 1929. Horton-Windsor district, Nova Scotia. Geological Survey of Canada, Memoir 155, $268 \mathrm{p}$.

1944. Carboniferous rocks, and fossil floras of northern Nova Scotia. Geological Survey of Canada, Memoir 238, 277 p.

Belt, E.S. 1968. Post-Acadian rifts and related facies, eastern Canada. In Studies of Appalachian Geology, Northern and Maritime. Edited by E-An Zen, W.S. White, J.B. Hadley and J.B. Thompson, Jr. Interscience, Toronto, pp. 95-113.

Bevier, M.L. and BARR, S.M. 1990. U-Pb age constraints on the stratigraphy and tectonic history of the Avalon terrane, New Brunswick. Journal of Geology, 98, pp. 53-63.

Bevier, M.L., White, C.E., and BArR, S.M. 1990. Late Precambrian $\mathrm{U}-\mathrm{Pb}$ ages for the Brookville Gneiss, southern New Brunswick. Journal of Geology, 98, pp. 955-965.

BIRD, J.M. and DEWEY, J.F. 1970. Lithosphere plate-continental margin tectonics and the evolution of the Appalachian orogen. Geological Society of America Bulletin, 81, pp. 1031-1060.

BlaIR, T.C. 1987. Tectonic and hydrologic controls on cyclic alluvial fan, fluvial, and lacustrine rift-basin sedimentation, Jurassic lowermost Cretaceous Todos Santos Formation, Chipas, Mexico. Journal of Sedimentary Petrology, 57, pp. 845-862.

Blair, T.C. and Bilodeau, W.L. 1988. Development of tectonic cyclothems in rift, pull-apart, and foreland basins: sedimentary response to episodic tectonism. Geology, 16, pp. 517-520.

BOEHNER, R.C. 1985. Windsor Group salt and potash in Nova Scotia, Canada. In Sixth International Symposium on Salt - 1983. Edited by B.C. Schreiber and H.L. Harner. The Salt Institute, Virginia, U.S.A., 1, pp. 99-113.

Boehner, R.C., Calder, J.H., Carter, D.C., Donohoe, H.V., JR., Ferguson, L., Pickerill, R.K., and Ryan, R.J. 1986. Carboniferous-Jurassic sedimentation and tectonics: Minas, Cumberland and Moncton Basins, Nova Scotia, and New Brunswick, (Symposium Field Trip). In Basins of eastern Canada and worldwide analogues symposium. Atlantic Geoscience Society with Canadian Society of Petroleum Geologists, Inter-Union Commission on the Lithosphere; Atlantic Geoscience Society, Special Publication 4, Halifax, Nova Scotia, $122 \mathrm{p}$

Bradley, D.C. 1982. Subsidence in Late Paleozoic basins in the northern Appalachians. Tectonics, 1, pp. 107-123.

BRown, R.L. and HelmstaedT, H. 1970. Deformation history in part of the Lubec-Belleisle zone of southern New Brunswick. Canadian Journal of Earth Sciences, 7, pp. 748-767.

BRowNe, G.H. 1990. The sedimentology of Boss Point Formation (Penn- sylvanian), eastern New Brunswick and northern Nova Scotia. Unpublished Ph.D. thesis, University of Western Ontario, London, Ontario, Volume I, pp. 1-382, Volume II, pp. 383-552.

Bull, W.B. 1972. Recognition of alluvial-fan deposits in the stratigraphic record. In Recognition of ancient sedimentary environments. Edited by J.K. Rigby and W.K. Hamblin. Society of Economic Paleontologists and Mineralogists, Special Publication 16, pp. 68-83.

CARR, P.A. 1968. Stratigraphy and spore assemblages, Moncton maparea, New Brunswick. Geological Survey of Canada, Paper 67$29,47 \mathrm{p}$.

CARTer, D.C. and Pickerill, R.K. 1985a. Algal swamp, marginal and shallow evaporitic lacustrine lithofacies from the Late DevonianEarly Carboniferous Albert Formation, southeastern New Brunswick, Canada. Maritime Sediments and Atlantic Geology, 21, pp. 69-86.

- 1985b. Lithostratigraphy of the Late Devonian-Early Carboniferous Horton Group of the Moncton Subbasin, southern New Brunswick. Maritime Sediments and Atlantic Geology, 21, pp. 11-24.

ChANDRA, J. 1982. Structural map of New Brunswick. New Brunswick Department of Natural Resources and Energy, Mineral Resources Division, Map-plate 82-178.

Crowell, J.C. 1974a. Origin of Late Cenozoic basins in southern California. In Tectonics and Sedimentation. Edited by W.R. Dickinson. Society of Economic Paleontologists and Mineralogists, Special Publication No. 22, pp. 190-204.

1974b. Sedimentation along the San Andreas Fault California. In Modern and ancient geosynclinal sedimentation. Edited by R.H. Dott and R.H. Shaver. Society of Economic Paleontologists and Mineralogists, Special Publication 19, pp. 292-303.

1987. The tectonically active margin of the western U.S.A. Episodes, 10, pp. 278-282.

CurRIE, K.L. 1989. Geology of the Saint John - Saint George area, New Brunswick (21 G/1, 2E, 7, 8; 21 H/4, 5W). Geological Survey of Canada, Open File Report 1974, 23 p.

DurLING, P.W. and Marillier, F.J.Y. 1990. Structural trends and basement rock subdivisions in the western Gulf of St. Lawrence, northern Appalachians. Atlantic Geology, 26, pp. 79-95.

EISBACHER, G.H. 1969. Displacement and stress field along part of the Cobequid Fault, Nova Scotia. Canadian Journal of Earth Sciences, 6, pp. 1095-1104.

Ferrill, B.A. and Thomas, W.A. 1988. Acadian dextral transpression and synorogenic sedimentary successions in the Appalachians. Geology, 16, pp. 604-608.

FlAGleR, P.A. 1989. A petrogenetic study of the Fournier oceanic complex, northern New Brunswick. Unpublished M.Sc. thesis, University of New Brunswick, Fredericton, New Brunswick, 251 p.

Foley, S.L. 1989. Geology of the Stoney Creek Oil and Gas Field, and its implications regarding the tectonic evolution of the eastern Moncton Subbasin New Brunswick. Department of Natural Resources and Energy, Minerals and Energy Division, Geoscience Report 89-1, 77 p.

Fralick, P.W. and Schenk, P.E. 1981. Molasse deposition and basin evolution in a wrench tectonic setting: the Late Paleozoic, eastem Cumberland Basin, Maritime Canada. In Sedimentation and tectonics in alluvial basins. Edited by A.D. Miall. Geological Association of Canada, Special Paper 23, pp. 77-97.

FyFFE, L.R. and BARR, S.M. 1986. Petrochemistry and tectonic significance of Carboniferous volcanic rocks in New Brunswick. Canadian Journal of Earth Sciences, 23, pp. 1243-1256.

FyFFe, L.R., MCLeod, M.J., and Rutenberg, A.A. 1991. A geotraverse across the St. Croix-Avalon terrane boundary, southern New Brunswick. In Geology of the coastal lithotectonic block and neighbouring terranes, eastern Maine and southern New 
Brunswick. Edited by A. Ludman. New England Intercollegiate Geological Conference 83rd Annual Meeting, Princeton, Maine. Wm. C. Brown Publishers, Debuque, Iowa, pp. 13-54.

Gates, O. 1989. The geology and geophysics of the Passamaquoddy Bay area, Maine and New Brunswick, and their bearing on local subsidence. In Neotectonics of Maine, studies in seismicity, crustal warping and sea level change. Edited by W.A. Anderson and H.W. Borns, Jr. Maine Geological Survey, Department of Conservation, Bulletin 40, pp. 11-24.

GeldSetzer, H.H.J. 1978. The Windsor Group in Atlantic Canada - an update. In Current Research, Part C, Geological Survey of Canada, Paper 78-1C, pp. 43-48.

Gibling, M.R. and Rust, B.R. 1986. Tectonic history of the Sydney Basin, Nova Scotia. In Basins of eastern Canada and worldwide analogues, symposium. Atlantic Geoscience Society with Canadian Society of Petroleum Geologists, Inter-Union Commission on the Lithosphere, Halifax, Nova Scotia, Programme with Abstracts, p. 50.

Gibling, M.R., Calder, J.H., Ryan, R., van de Poll, H.W., and Yeo, G.M. 1991. Late Carboniferous and Early Permian drainage patterns in Atlantic Canada. Canadian Journal of Earth Sciences, 29, pp. 338-352.

GloBENSKY, Y. 1970. Arenaceous foraminifera from the Windsor Group (Middle and Upper Mississippian of the Atlantic Provinces of Canada). Canadian Journal of Earth Sciences, 7, pp. 768-785.

GREINER, H.R. 1962. Facies and sedimentary environments of Albert shale, New Brunswick. American Association of Petroleum Geologists Bulletin, 46, pp. 219-234.

1974. The Albert Formation of New Brunswick: A Paleozoic lacustrine model. Geologische Rundschau, 63, pp. 1102-1113.

- 1977. Crossopterygian fauna from the Albert Formation, New Brunswick, Canada, and its stratigraphic-paleoecologic significance. Journal of Paleontology, 51, pp. 44-56.

Gussow, W.C. 1953. Carboniferous stratigraphy and structural geology of New Brunswick, Canada. American Association of Petroleum Geologists Bulletin, 37, pp. 1713-1816.

Hacquebard, P.A. 1972. The Carboniferous of eastern Canada. Compte Rendu, Seventh International Congress of Stratigraphy and Geology of the Carboniferous, Krefeld, Band 1, pp. 69-90.

Hamblin, A.P. 1989. Basin configuration, sedimentary facies, and resource potential of the Lower Carboniferous Horton Group, Cape Breton Island, Nova Scotia. In Current Research, Part B, Geological Survey of Canada, Paper 89-1B, pp. 115-120.

1992. Half-graben lacustrine sedimentary rocks of the Lower Carboniferous Strathlorne Formation, Horton Group, Cape Breton, Nova Scotia, Canada. Sedimentology, 39, pp. 263-284.

Hamilton, J.B. 1961. Salt in New Brunswick. New Brunswick Department of Lands and Mines, Mines Branch, Mineral Resource Report No. 1, 73 p.

Hardie, L.A., Smoot, J.P., and Eugster, H.P. 1978. Saline lakes and their deposits: a sedimentological approach. In Modern and Ancient Lake Sediments. Edited by A. Matter and M.E. Tucker. International Association of Sedimentologists, Special Publication 2, pp. 7-41.

HARDING, T.P. 1985. Seismic characteristics and identification of negative flower structures, positive flower structures and positive structural inversion. American Association of Petroleum Geologists Bulletin, 69, pp. 582-600.

Harland, W.B., Cox, A.V., Llewellyn, P.G., Pickton, C.A.G., Smith, A.G., and Walters, R. 1982. A geologic time scale. Cambridge University Press, Cambridge, $131 \mathrm{p}$.

Harland, W.B., Armstrong, R.L., Cox, A.V., Craig, L.E., Smith, A.G., and SMith, D.G. 1989. A geologic time scale 1989. Cambridge University Press, New York, 263 p.
HasZeldine, R.S. 1984. Carboniferous North Atlantic paleogeography: stratigraphic evidence for rifting, not megashear or subduction. Geological Magazine, 121, pp. 443-463.

Hesse, R. and Reading, H.G. 1978. Subaqueous clastic fissure eruptions and other examples of sedimentary transposition in the lacustrine Horton Bluff Formation (Mississippian), Nova Scotia, Canada. In Modern and Ancient Lake Sediments. Edited by A. Matter and M.E. Tucker. International Association of Sedimentologists, Special Publication 2, pp. 241-257.

Howie, R.D. 1968. Stoney Creek Gas and Oil Field, New Brunswick. In Natural gases of North America. Edited by B.W. Beebe and B.F. Curtis. American Association of Petroleum Geologists, Memoir 9, pp. 1819-1832.

1986. Windsor Group salt in the Cumberland Subbasin of Nova Scotia. Geological Survey of Canada, Paper 85-11, 12 p.

1988. Upper Paleozoic evaporites of southeastern Canada. Geological Survey of Canada, Bulletin 380, 120 p.

HowIE, R.D. and Barss, M.S. 1974. Upper Paleozoic rocks of the Atlantic Provinces, Gulf of St. Lawrence, and adjacent Continental Shelf. In Offshore geology of eastern Canada. Geological Survey of Canada, Paper 74-30, 2, pp. 35-50

1975. Paleogeography and sedimentation in the Upper Paleozoic, eastern Canada. In Canada's continental margins and offshore petroleum exploration. Edited by C.J. Yorath, E.R. Parker and D.J. Glass. Canadian Society of Petroleum Geologists, Memoir 4, pp. 45-57.

Howie, R.D. and Cumming, L.M. 1963. Basement features of the Canadian Appalachians. Geological Survey of Canada; Bulletin 89, $18 \mathrm{p}$.

Hyde, R.S. 1982. Geology of the Carboniferous Deer Lake Basin. Newfoundland and Labrador Department of Mines and Energy, Mineral Development Division, Map 82-7.

1989. The North Brook Formation: a temporal bridge spanning contrasting tectonic regions in the Deer Lake Basin, western Newfoundland. Atlantic Geology, 25, pp. 15-22.

KelLEY, D.G. 1967. Some aspects of Carboniferous stratigraphy and depositional history in the Atlantic Provinces. In Collected papers in geology of the Atlantic region. Edited by E.R.W. Neale and $\mathrm{H}$. Williams. Geological Association of Canada, Special Paper 4, pp. 213-228.

KePPIE, J.D. 1979. Geology map of the province of Nova Scotia. Nova Scotia Department of Mines and Energy, Nova Scotia.

1982. The Minas geofracture. In Major structural zones and faults of the northern Appalachians. Edited by P. St. Julien and J. Béland. Geological Association of Canada, Special Paper 24, pp. 263-280.

1985. The Appalachian collage. In The Caledonide orogen, Scandinavia and related areas. Edited by D.G. Gee and B.A. Sturt. John Wiley and Sons, New York, pp. 1217-1226.

1992. Structure of the Canadian Appalachian orogen. Nova Scotia Department of Natural Resources, Bulletin 7, 89 p.

KepPie, J.D. and Dallmeyer, R.D. 1987. Dating transcurrent terrane accretion: an example from the Meguma and Avalon composite terranes in the northern Appalachian orogen. Tectonics, 6, pp. 831-847.

Kingston, P.W. and Dickie, D.E. 1979. Geology of New Brunswick potash deposits. Canadian Institute of Mining and Metallurgy, Bulletin 72, pp. 134-141.

KNIGHT, I. 1983. Geology of the Carboniferous Bay St. George Subbasin, western Newfoundland. Newfoundland and Labrador Department of Mines and Energy, Mineral Development Division, Memoir 1, $358 \mathrm{p}$.

Koltermann, C.E. and Gorelick, S.M. 1992. Paleoclimatic signature in terrestrial flood deposits. Science, 256, pp. 1775-1782. 
Lambe, L.M. 1909. The fish fauna of the Albert Shales of New Brunswick. American Journal of Science, 178, Article XVIII, pp. 165-174.

Leger, A. 1986. Transcurrent faulting history of southern New Brunswick. Unpublished M.Sc. thesis, University of New Brunswick, Fredericton, New Brunswick, 170 p

Leger, A. and Williams, P.F. 1986. Transcurrent faulting history of southern New Brunswick. In Current Research, Part B, Geological Survey of Canada, Paper 86-1B, pp. 111-120.

Leger, A., Williams, P.F., and NANCE, R.D. 1988. Comment and reply on "Model for the Precambrian evolution of the Avalon terrane, southern New Brunswick, Canada". Geology, 16, pp. 475-476.

Legun, A.S. and Rust, B.R. 1982. The Upper Carboniferous Clifton Formation of northern New Brunswick: coal-bearing deposits of a semi-arid alluvial plain. Canadian Journal of Earth Sciences, 19, pp. 1775-1785.

Link, M.H. and Osborne, R.H. 1978. Lacustrine facies in the Pliocene Ridge Basin Group: Ridge Basin, California. In Modern and Ancient Lake Sediments. Edited by A. Matter and M.E. Tucker. International Association of Sedimentologists, Special Publication 2, pp. 169-187.

Link, M.H., Roberts, M.T., and Newton, M.S. 1985. Walker Lake Basin, Nevada, An example of late Tertiary (?) to Recent sedimentation in a basin adjacent to an active strike-slip fault. In Strike-slip deformation, basin formation, and sedimentation. Edited by K.T. Biddle and N. Christie-Blick. Society of Economic Paleontologists and Mineralogists, Special Publication 37, pp. 105-125.

Mann, P., Hempton, M.R., Bradley, D.C., and Burke, K. 1983. Development of pull-apart basins. Journal of Geology, 91, pp. 529-554.

Marillier, F., Keen, C.E., Stockmal, G.S., Quinlan, G., Williams, H., Colman-SADD, S.P., and O'Brien, S.J. 1989. Crustal structure and surface zonation of the Canadian Appalachians: implications of deep seismic reflection data. Canadian Journal of Earth Sciences, 26, pp. 305-321

MARTEL, A.T. 1987. Seismic stratigraphy and hydrocarbon potential of the strike-slip Sackville sub-basin, New Brunswick. In Sedimentary Basins and Basin-forming Mechanisms. Edited by C. Beaumont and A.J. Tankard. Canadian Society of Petroleum Geologists, Memoir 12, and Atlantic Geoscience Society, Special Publication 5, pp. 319-334.

- 1990. Stratigraphy, fluviolacustrine sedimentology and cyclicity of the Late Devonian/Early Carboniferous Horton Bluff Formation, Nova Scotia, Canada. Unpublished Ph.D. thesis, Dalhousie University, Halifax, Nova Scotia, 297 p

Mathews, R.K. 1974. Dynamic Stratigraphy. Prentice Hall, Incorporated, Englewood Cliffs, New Jersey, $370 p$

Mawer, C.K. and White, J.C. 1987. Sense of displacement on the Cobequid-Chedabucto fault system, Nova Scotia, Canada. Canadian Journal of Earth Sciences, 24, pp. 217-223.

McCutcheon, S.R. 1978. Geology of the Apohaqui-Markhamville area, map-area R-25 (21 H/11W, $21 \mathrm{H} / 12 \mathrm{E})$. New Brunswick Department of Natural Resources, Mineral Resources Branch, Map Report 78-5, $41 \mathrm{p}$.

1981a. Stratigraphy and paleogeography of the Windsor Group in southern New Brunswick. New Brunswick Department of Natural Resources, Mineral Resources Branch, Open File Report 81-31, 210 p.

$1981 \mathrm{~b}$. Revised stratigraphy of the Long Reach area, southern New Brunswick: Evidence for major, northwestward-directed Acadian thrusting. Canadian Journal of Earth Sciences, 18, pp. 646-656.

1985. Hopewell Group. In Lexicon of Canadian Stratigraphy, Volume VI, Atlantic Region. Edited by G.L. Williams, L.R. Fyffe,
R.J. Wardle, S.P. Colman-Sadd, R.C. Boehner and J.A. Watt. Canadian Society of Petroleum Geologists, Calgary, Alberta, pp. 175-176.

_ 1990. The Late Devonian Mount Pleasant Caldera Complex stratigraphy, mineralogy, geochemistry and geologic setting of a Sn-W deposit in southwestern New Brunswick. Unpublished Ph.D. thesis, Dalhousie University, Halifax, Nova Scotia, 609 p.

McCutcheon, S.R. and Robinson, P.T. 1987. Geologic constraints on the genesis of the Maritimes Basin, Atlantic Canada. In Sedimentary Basins and Basin-Forming mechanisms. Edited by $\mathrm{C}$ Beaumont and A.T. Tankard. Canadian Society of Petroleum Geologists, Memoir 12, and Atlantic Geoscience Society, Special Publication 5, pp. 287-297.

McCutcheon, S.R. and Ruitenberg, A.A. 1987. Geology and mineral deposits, Annidale-Nerepis area, New Brunswick. New Brunswick Department of Natural Resources and Energy, Mineral Resources Division, Memoir 2, $141 \mathrm{p}$.

McLeod, M.J. 1980. Geology and mineral deposits of the Hillsborough area, map-area V-22 and V-23 (Parts of $21 \mathrm{H} / 15 \mathrm{E}$ and $21 \mathrm{H} /$ 15W). New Brunswick Department of Natural Resources, Mineral Resources Branch, Map Report 79-6, 35 p.

McLeod, M.J. and Ruitenberg, A.A. 1978. Geology and mineral deposits of the Dorchester area, map area W-22, W-23 (21H/15E, $21 \mathrm{H} / 16 \mathrm{~W})$. New Brunswick Department of Natural Resources, Mineral Resources Branch, Map Report 78-4, 27 p.

McLeod, M.J., Johnson, S.C., and Ruitenberg, A.A. 1994. Geological map of southeastern New Brunswick. New Brunswick Department of Natural Resources and Energy, Map NR-6.

McPherson, J.G., Shanmugam, G., and Moiola, R.J. 1987. Fan deltas and braid deltas: varieties of coarse-grained deltas. Geological Society of America Bulletin, 99, pp. 331-340.

MiAll, A.D. 1978. Lithofacies types and vertical profile models in braided river deposits. A summary. In Fluvial Sedimentology Edited by A.D. Miall. Canadian Society of Petroleum Geologists, Memoir 5, pp. 597-604.

- 1981. Alluvial sedimentary basins: tectonic setting and basin architecture. In Sedimentation and tectonics in Alluvial Basins. Edited by A.D. Miall. Geological Association of Canada, Special Paper 23, pp. 1-33.

___ 1985. Architectural-element analysis: A new method of facies analysis applied to fluvial deposits. Earth Science Reviews, 22, pp. 261-308.

MoORE, R.G. 1985. Windsor Group. In Lexicon of Canadian Stratigraphy, Volume VI, Atlantic Region. Edited by G.L. Williams, L.R. Fyffe, R.J. Wardle, S.P. Colman-Sadd, R.C. Boehner and J.A. Watt. Canadian Society of Petroleum Geologists, Calgary, Alberta, pp. $401-402$

Morel, P. and IRVING, E. 1978. Tentative paleocontinental maps for the Early Phanerozoic and Proterozoic. Journal of Geology, 86, pp. 535-561.

Mosher, S. and Rast, N. 1984. The deformation and metamorphism of Carboniferous rocks in Maritime Canada and New England. In Variscan tectonics of the North Atlantic region. Edited by D.H.W. Hulton and D.J. Sanderson. Blackwell Scientific Publications, Boston, Massachusetts, pp. 233-243.

Nance, R.D. 1986a. Precambrian evolution of the Avalon terrane in the northern Appalachians. Maritime Sediments and Atlantic Geology, 22, pp. 214-239.

- 1986b. Late Carboniferous tectonostratigraphy in the Avalon terrane of southern New Brunswick. Maritime Sediments and Atlantic Geology, 22, pp. 308-326.

1987. Model for the Precambrian evolution of the Avalon terrane in southern New Brunswick. Geology, 15, pp. 753-756.

NANCE, R.D. and WARNER, J.B. 1986. Variscan tectonostratigraphy of 
the Mispec Group, southern New Brunswick: structural geometry and deformational history. In Current Research, Part A, Geological Survey of Canada, Paper 86-1A, pp. 351-358.

Norman, G.W.H. 1941. Hillsborough map sheet, Albert and Westmorland counties, New Brunswick. Geological Survey of Canada, Map 647A (with marginal notes).

Picard, M.D. and High, L.R., JR. 1972. Criteria for recognizing lacustrine rocks. In Recognition of ancient sedimentary environments. Edited by J.K. Rigby and W.K. Hamblin. Society of Economic Paleontologists and Mineralogists, Special Publication 16, pp. 108-145.

PiCKERILl, R.K. and CARTER, D. 1980. Sedimentary facies and depositional history of the Albert Formation. New Brunswick Department of Natural Resources, Mineral Resources Branch, Open File Report 80-2, 132 p.

Pickerill, R.K., Carter, D., and St. Peter, C. 1985. Albert Formation - oil shales, lakes, fans, and deltas. Geological Association of Canada/Mineralogical Association of Canada, Field Trip Guide, Excursion 6,75 p

Plint, A.G. and VAN DE Poll, H.W. 1984. Structural and sedimentary history of the Quaco Head area, southern New Brunswick. Canadian Journal of Earth Sciences, 21, pp. 753-761.

PoPPER, G.H.P. 1965. Stratigraphic and tectonic history of the Memramcook terrestrial red beds of New Brunswick, Canada. Unpublished M.Sc. thesis, University of Massachusetts, Amherst, Massachusetts, $129 \mathrm{p}$.

Potter, R.R., Hamilton, J.B., and Davies, J.L. 1979. Geological map of New Brunswick (second edition). New Brunswick Department of Natural Resources, Mineral Resources Branch, Map NR-1.

Rast, N. 1984. The Alleghenian orogeny in eastern North America. In Variscan tectonics of the North Atlantic region. Edited by D.H.W. Hutton and D.J. Sanderson. Blackwell Scientific Publications, Boston, pp. 197-217

1989. The evolution of the Appalachian chain. In The Geology of North America - An overview. Edited by A.W. Bally and A.R. Palmer. Geological Society of America, Boulder, Colorado, Volume A, pp. 323-348.

Rast, N. and Stringer, P. 1974. Recent advances and the interpretation of geological structure of New Brunswick. Geoscience Canada, 1, pp. 15-25.

1980. A geotraverse across a deformed Ordovician ophiolite and its Silurian cover, northern New Brunswick, Canada. Tectonophysics, 69 , pp. 221-245.

READING, H.G. 1980. Characteristics and recognition of strike-slip fault systems. In Sedimentation in Oblique-slip Mobile Zones. Edited by P.F. Ballance and H.G. Reading. International Association of Sedimentologists, Special Publication 4, pp. 7-26.

1982. Sedimentary basins and global tectonics. Geologists Association Proceedings, 93, pp. 321-350.

REEvES, C.C., JR. 1970. Origin, classification, and geologic history of caliche on the southern High Plains, Texas and eastern New Mexico. Journal of Geology, 78, pp. 352-362.

ReIneCK, H.-E. and Singh, I.B. 1980. Depositional Sedimentary Environments. Springer-Verlag, New York, 439 p.

Roliff, W.A. 1962. The Maritimes Carboniferous basin of eastern Canada. Geological Association of Canada, Proceedings, 14, pp. $21-41$.

Roulston, B.V. and WAUGH, D.C.E. 1981. A borate mineral assemblage from the Penobsquis and Salt Springs evaporite deposits of southern New Brunswick. Canadian Mineralogist, 19, pp. 291-301

RutenBerg, A.A. and McCutcheon, S.R. 1982. Acadian and Hercynian structural evolution of southern New Brunswick. In Major structural zones and faults of the northern Appalachians. Edited by $\mathrm{P}$
St. Julien and J. Béland. Geological Association of Canada, Special Paper 24, pp. 131-148.

Ruitenberg, A.A., Giles, P.S., Venugopal, D.V., Buttimer, S.M., MCCuTChEON, S.R., and ChANDRA, J. 1979. Geology and mineral deposits, Caledonia area. New Brunswick Department of Natural Resources, Mineral Resources Branch, and Canada Department of Regional Economic Expansion, Memoir 1, 213 p.

Rust, B.R. 1979. Facies Model 2, coarse alluvial deposits. In Facies Models. Edited by R.G. Walker. Geological Association of Canada, Geoscience Canada, Reprint Series 1, pp. 9-21.

1981. Alluvial deposits and tectonic style: Devonian and Carboniferous successions in eastern Gaspé. In Sedimentation and tectonics in alluvial basins. Edited by A.D. Miall. Geological Association of Canada, Special Paper 23, pp. 49-76.

Rust, B.R. and Koster, E.H. 1984. Coarse alluvial deposits. In Facies Models (second edition). Edited by R.G. Walker. Geological Association of Canada, Geoscience Canada, Reprint Series 1, pp. 53-69.

RYAN, R.J., and BOEHNER, R.C. 1990. Cumberland Basin geology map, Tatamagouche and Malagash, Cumberland, Colchester and Pictou counties. Nova Scotia Department of Mines and Energy, Map 90$14(1: 50,000)$.

RYAN, R.J., BoEHNER, R.C., and CALDER, J.H. 1991. Lithostratigraphic revisions of the upper Carboniferous to lower Permian strata in the Cumberland Basin, Nova Scotia and the regional implications for the Maritimes Basin in Atlantic Canada. Bulletin of Canadian Petroleum Geology, 39, pp. 289-314

Ryan, R.J., Boehner, R.C., and Deal, A. 1990a. Cumberland Basin geology map, Apple River and Cape Chignecto, Cumberland County. Nova Scotia Department of Mines and Energy, Map 90$11(1: 50,000)$

1990b. Cumberland Basin geology map, Amherst, Springhill and Parrsboro, Cumberland County. Nova Scotia Department of Mines and Energy, Map 90-12 (1:50,000).

1990c. Cumberland Basin geology map, Oxford and Pugwash, Cumberland County. Nova Scotia Department of Mines and Energy, Map 90-13 (1:50,000)

Ryan, R.J., Donohoe, H.V., JR., and Boehner, R.C. 1988. Sedimentation, tectonics and Carboniferous basin evolution adjacent to the Cobequid Highlands Massif, northern Nova Scotia. Abstract. Maritime Sediments and Atlantic Geology, 24, p. 211

St. Jean, J.A.R., Nance, R.D., and Murphy, J.B. 1993. Tectonic significance of Late Paleozoic deformation in the Cape George Peninsula, Antigonish Highlands, Nova Scotia. Atlantic Geology, 29 pp. $27-42$.

ST. PETER, C. 1982. Geology of the Albert Formation, New Brunswick, Canada. In Proceedings, 1982 Eastern Oil Shale Symposium Kentucky Department of Energy, University of Kentucky Institute for Mining and Minerals Research, pp. 39-47

1987. Geotectonic evolution of the Late Paleozoic Maritimes Basin. New Brunswick Department of Natural Resources and Energy, Minerals and Energy Division, Open File Report 87-14, $129 \mathrm{p}$.

1989. Geology of the Albert Formation, Moncton Subbasin New Brunswick Department of Natural Resources and Energy, Minerals and Energy Division, Map plates: 89-104A, 89-104B, 89-104C, 89-104D, 89-104E, 89-104F, 89-104G, 89-104H, 89$104 \mathrm{I}, 89-104 \mathrm{~J}, 89-104 \mathrm{~K}, 89-104 \mathrm{~L}, 89-104 \mathrm{M}$, and $89-104 \mathrm{~N}$.

1992a. Lithologic facies, seismic facies, and strike-slip setting of the Lower Carboniferous alluvial/fluvial/lacustrine Albert Formation of New Brunswick. Unpublished M.Sc. thesis, University of New Brunswick, Fredericton, New Brunswick, 229 p 1992b. Lithologic facies, seismic facies, and strike-slip setting of the Lower Carboniferous alluvial/fluvial/lacustrine Albert 
Formation of New Brunswick. New Brunswick Department of Natural Resources and Energy, Mineral Resources, Geoscience Report 92-2, 145 p.

St. Peter, C. and Fyffe, L.R. 1990. Structural trends and basement rock subdivisions in the western Gulf of St. Lawrence: Discussion. Atlantic Geology, 26, pp. 277-279.

Schenk, P.E. 1969. Carbonate-sulphate-red bed facies and cyclic sedimentation of the Windsorian stage (Middle Carboniferous), Maritime Provinces. Canadian Journal of Earth Sciences, 6, pp. 10371066.

SHRODER, J.F., JR. 1963. Stratigraphy and tectonic history of the Moncton Group of nonmarine redbeds of New Brunswick, Canada. Unpublished M.Sc. thesis, University of Massachusetts, Amherst, Massachusetts, $83 \mathrm{p}$.

Silverstone, B. 1982. Report \#1158 - On Millstream Seismic Interpretation. Unpublished BP Canada Report, 10 p. (Available in public files at New Brunswick Department of Natural Resources and Energy, Mineral Resources Division, Fredericton, New Brunswick.)

SMITH, L. and Collins, J.A. 1984. Unconformities, sedimentary copper mineralization, and thrust faulting in the Horton and Windsor groups, Cape Breton Island and central Nova Scotia. In Atlantic Coast Basins. Edited by H.H.J. Geldsetzer. Ninth International Congress, Carboniferous Stratigraphy and Geology, ChampaignUrbane, Illinois, Compte Rendu, Volume 3, Part 1, pp. 105-116.

SMith, W.D. 1985. Composition and depositional environment of the Albert Formation oil shales, New Brunswick. Unpublished M.Sc. thesis, Dalhousie University, Halifax, Nova Scotia, 286 p.

SMITH, W.D. and Gibling, M.R. 1987. Oil shale composition related to depositional setting: a case study from the Albert Formation, New Brunswick, Canada. Bulletin of Canadian Petroleum Geology, 35, pp. 469-487.

Smith, W.D., St. Peter, C., Mukhopadhyay, P.K., Naylor, R.D., Ball, F.D., Kalkreuth, W.D., and Macauley, G. 1991. Composition and depositional environment of Eastern Canadian oil shales. In International Journal of Coal Geology, 19, pp. 385-438.

SoegaArd, K. 1990. Fan-delta and braid-delta systems in Pennsylvanian Sandia Formation, Taos Trough, northern New Mexico: depositional and tectonic implications. Geological Society of America Bulletin, 102, pp. 1325-1343.

Stockmal, G.S., Colman-Sadd, S.P., Keen, C.E., O'Brien, S.J., and QUiNLAN, G. 1987. Collision along an irregular margin: a regional plate tectonic interpretation of the Canadian Appalachians. Canadian Journal of Earth Sciences, 24, pp. 1098-1107.

Stoffers, P. and Hecky, R.E. 1978. Late Pleistocene-Holocene evolution of the Kivu-Tanganyika Basin. In Modern and Ancient Lake Sediments. Edited by A. Matter and M.E. Tucker. International Association of Sedimentologists, Special Publication 2, pp. 4355 .

Stringer, P. and Burke, K.B.S. 1985. Structure in southwest New Brunswick. Excursion 9. Geological Association of Canada-Mineralogical Association of Canada, University of New Brunswick, Fredericton, New Brunswick, 34 p.

Stringer, P. and LAJTA, E.Z. 1979. Cleavage in Triassic rocks of southern New Brunswick, Canada. Canadian Journal of Earth Sciences, 16 , pp. 2165-2180.

Stringer, P., Burke, K.B.S., and DunN, T. 1991. Stratigraphy, structure, and associated igneous rocks of the Upper Devonian Perry Formation in the St. Andrews area, southwest New Brunswick, and adjacent coastal Maine. In Geology of the coastal lithotectonic block and neighbouring terranes, eastern Maine and southern New Brunswick. Edited by A. Ludman. New England Intercollegiate Geological Conference 83rd Annual Meeting, Princeton, Maine. Wm. C. Brown Publishers, Debuque, Iowa, pp. 222-264.

Sylvester, A.G. and SMith, R.R. 1976. Tectonic transpression and basement-controlled deformation in San Andreas fault zone, Salton Trough, California. American Association of Petroleum Geologists Bulletin, 60, pp. 2081-2102.

Utting, J. 1980. Palynology of the Windsor Group (Mississippian) in a borehole at Stewiacke, Shubenacadie Basin, Nova Scotia. Canadian Journal of Earth Sciences, 17, pp. 1031-1045.

1987. Palynostratigraphic investigation of the Albert Formation (Lower Carboniferous) of New Brunswick, Canada. Palynology, 11, pp. 73-96.

VAN DE POLL, H.W. 1970. Stratigraphy and sedimentological aspects of Pennsylvanian strata in southern New Brunswick. Unpublished Ph.D. thesis, University of Wales, Swansea, $199 \mathrm{p}$.

1978. Paleoclimatic control and stratigraphic limits of synsedimentary mineral occurrences in Mississippian-Early Pennsylvanian strata of eastern Canada. Economic Geology, 73, pp. 1069-1081.

1983. Geology of Prince Edward Island. Prince Edward Island Department of Energy and Forestry, Energy and Minerals Branch, Report 83-1, 66 p.

1989. Lithostratigraphy of the Prince Edward Island red beds. Atlantic Geology, 25, pp. 23-35.

VARMA, C.P. 1969. Lower Carboniferous miospores from the Albert oil shales (Horton Group) of New Brunswick, Canada. Micropaleontology, 15, pp. 301-324.

Wade, J.A., Grant, A.C., SANFord, B.V., and Barss, M.S. 1977. Basement structures, eastern Canada and adjacent areas. Geological Survey of Canada, Map 1400 A (4 sheets).

WAUGH, D.C.E. and URQuHART, B.R. 1985. The geology of DenisonPotacan's New Brunswick potash deposit. In Sixth International Symposium on Salt-1983. Edited by B.C. Schreiber and H.L. Harner. The Salt Institute, Virginia, U.S.A., 1, pp. 85-98.

WEBB, G.W. 1963. Occurrence and exploration significance of strikeslip faults in southern New Brunswick, Canada. American Association of Petroleum Geologists Bulletin, 47, pp. 1904-1927.

1969. Paleozoic wrench faults in Canadian Appalachians. In North Atlantic Geology and Continental Drift. Edited by M. Kay. American Association of Petroleum Geologists, Memoir 12, pp. 754-786.

WeBB, T.C. 1977. Geology of New Brunswick glauberite deposits. New Brunswick Department of Natural Resources, Mineral Resources Branch, Open File Report 77-15, 29 p.

Wilcox, R.E., Harding, T.P., and Seely, D.R. 1973. Basic wrench tectonics. American Association of Petroleum Geologists Bulletin, 57, pp. 74-96.

WiLliams, E.P. 1974. Geology and petroleum possibilities in and around Gulf of St. Lawrence. American Association of Petroleum Geologists Bulletin, 58, pp. 1137-1155.

Williams, H. 1979. Appalachian orogen in Canada. Canadian Journal of Earth Sciences, 16, pp. 792-807.

Williams, H. and HaTCHER, R.D., JR. 1982. Suspect terranes and accretionary history of the Appalachian orogen. Geology, 10, pp. 530536.

Williams, H., Colman-SAdD, S.P., and Swinden, H.S. 1988. Tectonicstratigraphic subdivisions of central Newfoundland. In Current Research, Part B, Geological Survey of Canada, Paper 88-1B, pp. 91-98.

Williams, P.F. and Hy, C. 1990. Origin and deformational and metamorphic history of gold-bearing quartz veins on the Eastern Shore of Nova Scotia. In Mineral Deposit studies in Nova Scotia, Volume 1. Edited by A.L. Sangster. Geological Survey of Canada, Paper 90-8, pp. 169-194.

Williams, P.F. and RUST, B.R. 1969. The sedimentology of a braided river. Journal of Sedimentary Petrology, 39, pp. 649-679.

Woodcock, N.H. and Fischer, M. 1986. Strike-slip duplexes. Journal of Structural Geology, 8, pp. 725-735. 
Worth, J.K. 1977. Oil shale and lithofacies, Albert Formation, Hillsborough Sub-basin, New Brunswick. Fundy Geoservices Limited, Report for Canadian Occidental Petroleum Limited, $90 \mathrm{p}$.

WRIGHT, W.J. 1922. Geology of the Moncton map-area. Canada Department of Mines, Geological Survey, Memoir 129, 69 p.

YEO, G.M. 1985. Upper Carboniferous sedimentation in northern Nova Scotia and the origin of Stellarton Basin. In Current Research, Part B, Geological Survey of Canada, Paper 85-1B, pp. 511-518.

Yeo, G.M. and Ruixing (sic), G. 1986. Late Carboniferous dextral movement on the Cobequid-Hollow fault system, Nova Scotia: evidence and implications. In Current Research, Part A, Geological Survey of Canada, Paper 86-1A, pp. 399-410.

1987. Stellarton Graben: an Upper Carboniferous pull-apart basin in northern Nova Scotia. In Sedimentary Basins and Basinforming Mechanisms. Edited by C. Beaumont and A.J. Tankard. Canadian Society of Petroleum Geologists, Memoir 12, and Atlantic Geoscience Society, Special Publication 5, pp. 299-309. 